\title{
Characterization of aerosol composition, aerosol acidity, and organic acid partitioning at an agriculturally intensive rural southeastern US site
}

\author{
Theodora Nah ${ }^{1, \mathrm{a}}$, Hongyu Guo ${ }^{1}$, Amy P. Sullivan ${ }^{2}$, Yunle Chen ${ }^{1}$, David J. Tanner ${ }^{1}$, Athanasios Nenes ${ }^{1,3,4,5}$, \\ Armistead Russell ${ }^{6}$, Nga Lee Ng $^{1,3}$, L. Gregory Huey ${ }^{1}$, and Rodney J. Weber ${ }^{1}$ \\ ${ }^{1}$ School of Earth and Atmospheric Sciences, Georgia Institute of Technology, Atlanta, GA, USA \\ ${ }^{2}$ Department of Atmospheric Science, Colorado State University, Fort Collins, CO, USA \\ ${ }^{3}$ School of Chemical and Biomolecular Engineering, Georgia Institute of Technology, Atlanta, GA, USA \\ ${ }^{4}$ ICE-HT, Foundation for Research and Technology, Hellas, 26504 Patras, Greece \\ ${ }^{5}$ IERSD, National Observatory of Athens, P. Penteli, 15236 Athens, Greece \\ ${ }^{6}$ School of Civil and Environmental Engineering, Georgia Institute of Technology, Atlanta, GA, USA \\ ${ }^{a}$ now at: School of Energy and Environment, City University of Hong Kong, Kowloon, Hong Kong, China
}

Correspondence: Rodney J. Weber (rweber@eas.gatech.edu)

Received: 10 April 2018 - Discussion started: 26 April 2018

Revised: 6 August 2018 - Accepted: 7 August 2018 - Published: 15 August 2018

\begin{abstract}
The implementation of stringent emission regulations has resulted in the decline of anthropogenic pollutants including sulfur dioxide $\left(\mathrm{SO}_{2}\right)$, nitrogen oxides $\left(\mathrm{NO}_{x}\right)$, and carbon monoxide $(\mathrm{CO})$. In contrast, ammonia $\left(\mathrm{NH}_{3}\right)$ emissions are largely unregulated, with emissions projected to increase in the future. We present real-time aerosol and gas measurements from a field study conducted in an agriculturally intensive region in the southeastern US during the fall of 2016 to investigate how $\mathrm{NH}_{3}$ affects particle acidity and secondary organic aerosol (SOA) formation via the gas-particle partitioning of semi-volatile organic acids. Particle water and $\mathrm{pH}$ were determined using the ISORROPIA II thermodynamic model and validated by comparing predicted inorganic $\mathrm{HNO}_{3}-\mathrm{NO}_{3}^{-}$and $\mathrm{NH}_{3}-\mathrm{NH}_{4}^{+}$gas-particle partitioning ratios with measured values. Our results showed that despite the high $\mathrm{NH}_{3}$ concentrations (average 8.1 $\pm 5.2 \mathrm{ppb}$ ), $\mathrm{PM}_{1}$ was highly acidic with $\mathrm{pH}$ values ranging from 0.9 to 3.8 , and an average $\mathrm{pH}$ of $2.2 \pm 0.6 . \mathrm{PM}_{1} \mathrm{pH}$ varied by approximately 1.4 units diurnally. Formic and acetic acids were the most abundant gas-phase organic acids, and oxalate was the most abundant particle-phase water-soluble organic acid anion. Measured particle-phase water-soluble organic acids were on average $6 \%$ of the total non-refractory $\mathrm{PM}_{1}$ organic aerosol mass. The measured molar fraction of oxalic acid in the particle phase (i.e., particle-phase oxalic acid molar con-
\end{abstract}

centration divided by the total oxalic acid molar concentration) ranged between $47 \%$ and $90 \%$ for a $\mathrm{PM}_{1} \mathrm{pH}$ of 1.2 to 3.4. The measured oxalic acid gas-particle partitioning ratios were in good agreement with their corresponding thermodynamic predictions, calculated based on oxalic acid's physicochemical properties, ambient temperature, particle water, and $\mathrm{pH}$. In contrast, gas-particle partitioning ratios of formic and acetic acids were not well predicted for reasons currently unknown. For this study, higher $\mathrm{NH}_{3}$ concentrations relative to what has been measured in the region in previous studies had minor effects on $\mathrm{PM}_{1}$ organic acids and their influence on the overall organic aerosol and $\mathrm{PM}_{1}$ mass concentrations.

\section{Introduction}

Ammonia $\left(\mathrm{NH}_{3}\right)$ is the most abundant basic gas in the troposphere and plays an important role in many atmospheric processes. It is a major neutralizer of atmospheric acidic species, reacting readily with sulfuric acid $\left(\mathrm{H}_{2} \mathrm{SO}_{4}\right)$ and nitric acid $\left(\mathrm{HNO}_{3}\right)$ to form ammonium sulfate and nitrate salts (e.g., $\left(\mathrm{NH}_{4}\right)_{2} \mathrm{SO}_{4}$, and other forms such as $\mathrm{NH}_{4} \mathrm{HSO}_{4}$, $\left(\mathrm{NH}_{4}\right)_{3} \mathrm{H}\left(\mathrm{SO}_{4}\right)_{2}$, and $\left.\mathrm{NH}_{4} \mathrm{NO}_{3}\right)$, which are often the main inorganic components of atmospheric aerosols. The forma- 
tion of particle-phase ammonium sulfate and nitrate salts in the aerosol phase depends on the thermodynamic states of their precursors and the environmental conditions, which can consequently affect aerosol pH. For example, Guo et al. (2017b) showed that for southeastern US summertime conditions, as aerosol $\mathrm{pH}$ increases, the relative fractions of $\mathrm{SO}_{4}^{2-}$ and $\mathrm{HSO}_{4}^{-}$increase and decrease, respectively. Wet and dry deposition are the principle $\mathrm{NH}_{3}$ sinks (Dentener and Crutzen, 1994). $\mathrm{NH}_{3}$ is spatially heterogeneous, with the highest concentrations typically found near emission sources (Seinfeld and Pandis, 2016). The dominant $\mathrm{NH}_{3}$ sources in rural areas are agricultural in nature, and include the application of fertilizers and volatilization of livestock waste (Reis et al., 2009; Ellis et al., 2013; Van Damme et al., 2014). Biomass burning, either from wildfires or from controlled burning during land-clearing operations, is also a significant source of $\mathrm{NH}_{3}$ in rural environments. The primary source of $\mathrm{NH}_{3}$ in urban areas is industrial emissions (e.g., $\mathrm{NH}_{3}$ synthesis, manufacture of ammonium nitrate and urea, fluid, and thermal catalytic cracking processes in petroleum refineries), though vehicular emissions can be a significant $\mathrm{NH}_{3}$ source in some heavily populated cities (Reis et al., 2009; Lamarque et al., 2010; Yao et al., 2013; Sun et al., 2017). Vehicular $\mathrm{NH}_{3}$ emissions are thought to be produced primarily from the reaction of nitrogen oxide with hydrogen in the presence of carbon monoxide in three-way catalysts of gasoline lightduty vehicles (Barbier Jr. and Duprez, 1994; Whittington et al., 1995; Livingston et al., 2009; Suarez-Bertoa et al., 2014).

In the US, implementation of stringent emission controls on traditional anthropogenic air pollutants, such as sulfur dioxide $\left(\mathrm{SO}_{2}\right)$, nitrogen oxides $\left(\mathrm{NO}_{x}\right)$, and carbon monoxide (CO), have led to steady decreases in their emissions, and consequently their concentrations (Blanchard et al., 2013b; Xing et al., 2013). In contrast, $\mathrm{NH}_{3}$ emissions are largely unregulated and are projected to increase due to increased agricultural operations to feed a growing world population (Reis et al., 2009; Ellis et al., 2013). Satellite observations showed that gas-phase $\mathrm{NH}_{3}$ concentrations have increased substantially in US agricultural areas from 2002 to 2014 (Warner et al., 2017). More wildfires from a changing climate, or from controlled burning for land clearing for agricultural use, may also lead to increased $\mathrm{NH}_{3}$ emissions (Reis et al., 2009; Pechony and Shindell, 2010; Warner et al., 2016). These trends suggest that $\mathrm{NH}_{3}$ could play an increasingly important role in atmospheric chemistry.

Previous laboratory studies have shown that $\mathrm{NH}_{3}$ can influence secondary organic aerosol (SOA) formation and processing. For example, $\mathrm{NH}_{3}$ increases $\mathrm{SOA}$ mass yields in the $\alpha$-pinene ozonolysis system and is hypothesized to be due to the formation of ammonium salts from the reaction of $\mathrm{NH}_{3}$ with organic acids (Na et al., 2007). The heterogeneous uptake of $\mathrm{NH}_{3}$ by $\mathrm{SOA}$ can also lead to the formation of particulate organonitrogen compounds, a class of brown carbon species that can reduce visibility and impact climate
(J. Laskin et al., 2010; Updyke et al., 2012; Lee et al., 2013; A. Laskin et al., 2015).

The southeastern US is a natural outdoor laboratory for studying the effects of biogenic-anthropogenic interactions on atmospheric aerosol formation and processing. Subtropical vegetation composed mainly of mixed conifer and deciduous forests emits large quantities of biogenic volatile organic compounds (BVOCs) that can act as precursors for SOA formation (Blanchard et al., 2011, 2013a; Guenther et al., 2012). Large urban centers and small towns are surrounded by large expanses of forests and widespread rural areas with agricultural activities. Scattered within the southeastern US are also coal-burning power plants and industrial facilities. Anthropogenic activities in this region emit large concentrations of VOCs, $\mathrm{SO}_{2}, \mathrm{NO}_{x}, \mathrm{CO}, \mathrm{NH}_{3}$, and aerosols (Blanchard et al., 2013c). Similar to other parts of the US, $\mathrm{SO}_{2}, \mathrm{CO}$, and $\mathrm{NO}_{x}$ concentrations have decreased steadily in the southeastern US due to the implementation of emission controls (Blanchard et al., 2013b). In contrast, gas-phase $\mathrm{NH}_{3}$ concentrations have increased in the southeastern US over the same time period (Saylor et al., 2015). These factors make the southeastern US an intriguing place to study the influence of $\mathrm{NH}_{3}$ on atmospheric aerosol chemistry.

We performed aerosol and gas measurements during a field study conducted in Yorkville, Georgia, US, in the fall of 2016, with the goal of understanding how $\mathrm{NH}_{3}$ affects aerosol acidity and SOA formation. The field site is surrounded by forest and agricultural land, affording an opportunity to make ambient observations in an area impacted by local emissions of BVOCs and $\mathrm{NH}_{3}$. In this paper, we present gas and aerosol composition measurements that include a suite of organic acids. The thermodynamic equilibrium model, ISORROPIA II, is used to calculate particle water and $\mathrm{pH}$ based on measured inorganic aerosol and gas composition (Nenes et al., 1998; Fountoukis and Nenes, 2007), and these predictions are compared to observed gas-particle partitioning of $\mathrm{NH}_{3}, \mathrm{HNO}_{3}$, and organic acids. Together, these measurements are used to determine how aerosol acidity affects the mass concentration of particle-phase organic acids at this site.

\section{Methods}

\subsection{Field site}

Aerosol and gas measurements were conducted at the Yorkville, Georgia $\left(33.929^{\circ} \mathrm{N}, 85.046^{\circ} \mathrm{W}\right)$ SouthEastern Aerosol Research and Characterization (SEARCH) field site from mid-August to mid-October 2016. This is one of the sampling sites for the Southeastern Center for Air Pollution and Epidemiology (SCAPE) study in which aerosol characterization measurements were conducted in the summer and winter of 2012 (Xu et al., 2015a, b). A detailed description of the field site can be found in Hansen et al. (2003). This 
rural site is situated in a mixed forest-agriculture area approximately $55 \mathrm{~km}$ northwest and generally upwind of Atlanta. The immediate surrounding area is used for cattle grazing and poultry concentrated animal feeding operations (CAFOs) (Fig. S1 in the Supplement). There are no major roads near the field site and nearby traffic emissions were negligible. A large coal-fired power plant (Plant Bowen) is situated approximately $25 \mathrm{~km}$ north of the site. Hence, the field site is impacted mainly by BVOC and $\mathrm{NH}_{3}$ emissions, with occasional spikes in $\mathrm{SO}_{2}$ and minimal influence from urban anthropogenic pollutants such as $\mathrm{HNO}_{3}, \mathrm{O}_{3}, \mathrm{NO}_{x}$, and $\mathrm{CO}$ (Fig. S2). The sampling period was characterized by moderate temperatures $\left(24.0^{\circ} \mathrm{C}\right.$ average, $32.6^{\circ} \mathrm{C}$ maximum, $9.5^{\circ} \mathrm{C}$ minimum) and high relative humidities (RHs) $(68.9 \%$ RH average, $100 \% \mathrm{RH}$ maximum, $21.6 \% \mathrm{RH}$ minimum). Meteorological data are shown in Fig. S3. Data reported are displayed in eastern daylight time (EDT).

\subsection{Instrumentation}

Instruments were housed in a temperature-controlled ( $\sim$ $20^{\circ} \mathrm{C}$ ) trailer during the field study. Gas-phase $\mathrm{HNO}_{3}, \mathrm{SO}_{2}$, and organic acids (formic, acetic, oxalic, butyric, glycolic, propionic, valeric, malonic, and succinic acids) were measured with a custom-built chemical ionization mass spectrometer (CIMS) using sulfur hexafluoride ions $\left(\mathrm{SF}_{6}^{-}\right)$as reagent ions. $\mathrm{SO}_{2}$ and $\mathrm{HNO}_{3}$ were detected as fluoride adducts $\left(\mathrm{F}_{2} \mathrm{SO}_{2}^{-}\right.$and $\mathrm{NO}_{3}^{-} \cdot \mathrm{HF}$, respectively) while the organic acids (HX) were detected primarily as conjugated anions $\left(\mathrm{X}^{-}\right)$using the quadrupole mass spectrometer (Huey et al., 1995, 2004; Nah et al., 2018). This CIMS is referred to hereafter as the $\mathrm{SF}_{6}$-CIMS. Gas-phase $\mathrm{NH}_{3}$ was measured with an additional custom-built CIMS using protonated ethanol clusters $\left(\left(\mathrm{C}_{2} \mathrm{H}_{5} \mathrm{OH}\right)_{n}^{+}\right)$as reagent ions. $\mathrm{NH}_{3}$ was detected primarily as $\mathrm{NH}_{4}^{+}$ions with the quadrupole mass spectrometer (Nowak et al., 2002; Yu and Lee, 2012; You et al., 2014a). This CIMS is referred to hereafter as the $\mathrm{NH}_{3}$-CIMS.

Since $\mathrm{HNO}_{3}, \mathrm{NH}_{3}$, and organic acids may condense on surfaces, both $\mathrm{SF}_{6}$-CIMS and $\mathrm{NH}_{3}$-CIMS used inlet configurations that minimized wall interactions (Huey et al., 2004; Nowak et al., 2006). Each CIMS was connected to an inlet (a $7.6 \mathrm{~cm}$ ID aluminum pipe) that protruded beyond the trailer's wall by $\sim 40 \mathrm{~cm}$ into the ambient air. Both inlets were $\sim 2 \mathrm{~m}$ above the ground. A donut-shaped ring was attached to the ambient sampling port of each pipe to curtail the influence of crosswinds on the pipe's flow dynamics. Both rings were wrapped with a fine wire mesh to prevent ingestion of insects. A flow of $\sim 2800 \mathrm{~L} \mathrm{~min}^{-1}$ was maintained in each pipe using regenerative blowers (Ametek Windjammer 116637-03). Part of this flow $\left(7 \mathrm{~L} \mathrm{~min}^{-1}\right.$ for the $\mathrm{SF}_{6}$ CIMS and $4.6 \mathrm{Lmin}^{-1}$ for the $\mathrm{NH}_{3}$-CIMS) was sampled through a custom-made three-way PFA Teflon valve, which connected the pipe's center to the CIMS sampling orifice and could be switched automatically between ambient and background measurements.
Background measurements were performed every $25 \mathrm{~min}$ for 4 min for both the $\mathrm{SF}_{6}$-CIMS and $\mathrm{NH}_{3}$-CIMS. During each background measurement, the sampled air flow was passed through an activated charcoal scrubber (Sigma Aldrich) that removed $\mathrm{SO}_{2}, \mathrm{HNO}_{3}$, and organic acids prior to delivery into the $\mathrm{SF}_{6}$-CIMS, and through a silicon phosphate scrubber (Perma Pure LLC) that removed $\mathrm{NH}_{3}$ prior to delivery into the $\mathrm{NH}_{3}$-CIMS. More than $99 \%$ of the targeted species were removed during background measurements for both the $\mathrm{SF}_{6}$-CIMS and $\mathrm{NH}_{3}$-CIMS. Standard addition calibrations were performed every $5 \mathrm{~h}$ for the $\mathrm{SF}_{6}$-CIMS using the outputs of a $1.12 \mathrm{ppm}{ }^{34} \mathrm{SO}_{2}$ gas cylinder (Scott Marrin Inc.) and a formic or acetic acid permeation device (VICI Metronics). Calibrations for the other gases measured by the $\mathrm{SF}_{6}$-CIMS were performed in post-field laboratory work, details of which can be found in Nah et al. (2018) and Supplement Sect. S1. Standard addition calibrations were performed hourly for the $\mathrm{NH}_{3}$-CIMS using the output of a $\mathrm{NH}_{3}$ permeation device (KIN-TEK). The outputs of the formic and acetic acid permeation devices were measured periodically by scrubbing the output of the permeation tube in deionized water, followed by ion chromatography analysis for formate and acetate. The emission rate of the $\mathrm{NH}_{3}$ permeation device was measured using UV optical absorption (Neuman et al., 2003).

The detection limits for species measured by the $\mathrm{SF}_{6}$ CIMS and $\mathrm{NH}_{3}$-CIMS were approximated from 3 times the standard deviation values $(3 \sigma)$ of the ion signals measured during background mode. The detection limits for $\mathrm{HNO}_{3}$, $\mathrm{SO}_{2}$, and the various organic acids measured by the $\mathrm{SF}_{6}$ CIMS ranged from 1 to $60 \mathrm{ppt}$ for $2.5 \mathrm{~min}$ integration periods, which corresponded to the length of a background measurement with a $\sim 4 \%$ duty cycle for each $\mathrm{m} / z$ (Table $\mathrm{S} 1$ in the Supplement). Measurement uncertainties for the concentrations of $\mathrm{HNO}_{3}, \mathrm{SO}_{2}$, and the various organic acids originate mainly from calibration measurements and were between $12 \%$ and $25 \%$ (Table S1). The detection limit for $\mathrm{NH}_{3}$ measured by the $\mathrm{NH}_{3}$-CIMS was $1 \mathrm{ppb}$ for 2.3 min integration periods, which corresponded to the length of a background measurement with a $\sim 29 \%$ duty cycle for the $\mathrm{NH}_{4}^{+}$ ion. Measurement uncertainties for $\mathrm{NH}_{3}$ concentrations were $13 \%$.

A high-resolution time-of-flight aerosol mass spectrometer (HR-ToF-AMS, Aerodyne Research Inc.) was used to measure the elemental composition of ambient nonrefractory $\mathrm{PM}_{1}$ (particles with aerodynamic diameters < $1 \mu \mathrm{m})$. Ambient air was sampled at $16.7 \mathrm{~L} \mathrm{~min}^{-1}$ through a URG $\mathrm{PM}_{1}$ cyclone and then through a Nafion dryer prior to delivery into the HR-ToF-AMS. Aerosols were dried to $\mathrm{RH}<20 \%$ to eliminate the influence of RH on the HR-ToFAMS's particle collection efficiency. A detailed description of the HR-ToF-AMS can be found in the literature (DeCarlo et al., 2006; Canagaratna et al., 2007, 2015). Briefly, the aerodynamic lens of the HR-ToF-AMS focused the dried submicron aerosols into a narrow beam. The aerosols were then im- 
pacted onto a heated tungsten surface $\left(\sim 600^{\circ} \mathrm{C}\right)$ on which they were flash vaporized. The resulting vapors were ionized by electron impact ionization $(70 \mathrm{eV})$, and the ions were detected by a time-of-flight mass spectrometer. Gas-phase interferences were accounted for by subtracting the signals obtained during daily measurements of filtered, particle-free sampling air. Ionization efficiency calibrations were performed weekly using $300 \mathrm{~nm}$ ammonium nitrate and ammonium sulfate particles. Composition-dependent collection efficiency (CDCE) values of 0.44 to 0.55 were determined using the procedure detailed by Middlebrook et al. (2012), in which CDCE values are derived based largely on aerosol inorganic species concentrations and the RH in the sampling line. In addition, a constant collection efficiency (CE) value of 0.9 was determined from the comparison of raw HR-ToFAMS SO 4 - data with other particulate $\mathrm{SO}_{4}^{2-}$ measurements performed during the study. Comparisons of aerosol mass concentrations obtained from the application of CDCE values (i.e., 0.44 to 0.55 ) vs. a constant $\mathrm{CE}$ value (i.e., 0.9) to the raw HR-ToF-AMS data are discussed in Sect. 3.2. Uncertainties in HR-ToF-AMS measurements were estimated to be approximately $25 \%$ (Canagaratna et al., 2007).

Particle-phase water-soluble organic acids and inorganic cations and anions were measured using two particleinto-liquid sampler (PILS) systems coupled to ion chromatographs (ICs) (Orsini et al., 2003). Each PILS sampled ambient air at nominally $16.7 \mathrm{~L} \mathrm{~min}^{-1}$ through a URG PM cyclone. Before PILS1, which was used to measure watersoluble inorganic cation and anions, two long $(24 \mathrm{~cm})$ URG glass annular denuders coated with sodium carbonate and phosphorous acid were used to remove acidic and basic gases. Before PILS2, which measured water-soluble organic acids, a $28 \mathrm{~cm}$ parallel plate carbon denuder (Sunset Lab) was used to remove organic gases (Eatough et al., 1993). In each PILS, aerosols were mixed with water vapor at $\sim 100^{\circ} \mathrm{C}$ generated from heated ultrapure deionized water (Weber et al., 2001; Orsini et al., 2003). The resulting droplets were impacted onto a plate, with the resulting liquid sample analyzed using the ICs. Each IC system was calibrated at the beginning and end of the study using five multi-compound standards in order to create calibration curves. Periodically, a HEPA filter (Pall Life Sciences) was placed on the inlet to determine the background in near real time. The measurement uncertainty for each IC system was about $10 \%$.

PILS1 was connected to two Dionex ICS-1500 ICs (Thermo Fisher Scientific) to measure the water-soluble inorganic ions. These two IC systems include an isocratic pump, self-regenerating anion or cation suppressor, and conductivity detector. This system will be referred to hereafter as the PILS-IC. Anions were separated using a Dionex IonPac AS15 guard and analytical column $(4 \times 250 \mathrm{~mm}$, Thermo Fisher Scientific) employing an eluent of $38 \mathrm{mM}$ sodium hydroxide at a flow rate of $1.5 \mathrm{~mL} \mathrm{~min}^{-1}$. Cations were separated using a Dionex IonPac CS12A guard and analytical column $(4 \times 250 \mathrm{~mm}$, Thermo Fisher Scientific $)$ employ- ing an eluent of $18 \mathrm{mM}$ methanesulfonic acid at a flow rate of $1 \mathrm{~mL} \mathrm{~min}^{-1}$. A new chromatogram was obtained every 30 min with a sample loop fill time (i.e., ambient sample integration time) of $20 \mathrm{~min}$. The limit of detection for the various anions and cations was approximately $0.01 \mu \mathrm{g} \mathrm{m}^{-3}$.

PILS2 was coupled to a Dionex ICS-4000 capillary highpressure ion chromatography (HPIC) system to measure the water-soluble organic acids. The HPIC includes an eluent generator, isocratic pump, degausser, suppressor, carbonate removal device, and conductivity detector. This system will be referred to hereafter as the PILS-HPIC. The organic acids were separated using a Dionex AS11-HC-4 $\mu \mathrm{m}$ capillary guard and analytical column $(0.4 \times 250 \mathrm{~mm}$, Thermo Fisher Scientific), which used a potassium hydroxide gradient separation method at a flow rate of $0.015 \mathrm{~mL} \mathrm{~min}^{-1}$. A new chromatogram was obtained every $60 \mathrm{~min}$ with a sample loop fill time of $2 \mathrm{~min}$. The limit of detection for the various organic acids was approximately $0.001 \mu \mathrm{g} \mathrm{m}^{-3}$.

Particle- and gas-phase water-soluble organic carbon $\left(\mathrm{WSOC}_{\mathrm{p}}\right.$ and $\mathrm{WSOC}_{\mathrm{g}}$, respectively) were measured using two Sievers 900 series total organic carbon (TOC) analyzers (GE Analytical Instruments), as described by Sullivan et al. (2004). For $\mathrm{WSOC}_{\mathrm{p}}$ measurements, ambient air was sampled at $15.2 \mathrm{~L} \mathrm{~min}^{-1}$ through a URG PM ${ }_{1}$ cyclone and a parallel plate carbon denuder into a PILS coupled to the first TOC analyzer. For $\mathrm{WSOC}_{\mathrm{g}}$ measurements, ambient air was sampled at $20 \mathrm{~L} \mathrm{~min}^{-1}$ through a Teflon filter $(45 \mathrm{~mm}$ diameter, $2.0 \mu \mathrm{m}$ pore size, Pall Life Sciences) to remove particles in the air stream. This filter was changed every 3 to 4 days. The particle-free air was then directed to a MIST chamber filled with ultrapure deionized water, which scrubbed the soluble gases at an air flow rate of $20 \mathrm{~L} \mathrm{~min}^{-1}$. Soluble gases with Henry's law constants greater than $10^{3}$ mole L $^{-1} \mathrm{~atm}^{-1}$ were scrubbed into deionized water in the MIST chamber (Spaulding et al., 2002). The resulting MIST chamber liquid sample was analyzed by the second TOC analyzer. The TOC analyzers converted the organic carbon in the liquid samples to carbon dioxide using UV radiation and chemical oxidation. The carbon dioxide formed was then measured by conductivity. The amount of organic carbon in the liquid samples is proportional to the measured increase in conductivity of the dissolved carbon dioxide. Each $\mathrm{WSOC}_{\mathrm{p}}$ and $\mathrm{WSOC}_{\mathrm{g}}$ measurement lasted $4 \mathrm{~min}$. Background $\mathrm{WSOC}_{\mathrm{p}}$ and $\mathrm{WSOC}_{\mathrm{g}}$ measurements were performed for 45 min every $12 \mathrm{~h}$ by stopping the sample air flow and rinsing the system with deionized water. Both TOC analyzers were calibrated at the beginning and end of the study using varying concentrations of sucrose solutions to create calibration curves (as specified by the instrument manual). The limit of detections for $\mathrm{WSOC}_{\mathrm{p}}$ and $\mathrm{WSOC}_{\mathrm{g}}$ were 0.2 and $0.4 \mu \mathrm{g} \mathrm{Cm}{ }^{-3}$, respectively. The measurement uncertainties for $\mathrm{WSOC}_{\mathrm{p}}$ and WSOC $_{\mathrm{g}}$ were estimated to be $10 \%$ based on uncertainties in the TOC analyzer, sample air, and liquid flows.

A suite of instruments operated by the SEARCH network provided supporting gas and aerosol measurements 
(Hansen et al., 2003; Edgerton et al., 2005, 2006, 2007). $\mathrm{O}_{3}$ was measured with a UV absorption instrument (Thermo Fisher Scientific) with a temporal resolution of $1 \mathrm{~min}$. NO and $\mathrm{NO}_{x}$ were measured using a chemiluminescence instrument (Thermo Fisher Scientific) with a temporal resolution of $1 \mathrm{~min}$. $\mathrm{NO}_{2}$ was obtained from the difference between $\mathrm{NO}$ and $\mathrm{NO}_{x}$. $\mathrm{CO}$ was measured using a nondispersive infrared absorption instrument (Thermo Fisher Scientific) with a temporal resolution of $1 \mathrm{~min}$. $\mathrm{NH}_{3}$ was measured by a denuder-based instrument (ARA) with a temporal resolution of $5 \mathrm{~min}$. Comparisons of measurements by the $\mathrm{NH}_{3}$-CIMS and denuder-based instrument will be presented in Sect. 3.1. A filter-based particle composition monitor (ARA) provided $24 \mathrm{~h}$-integrated $\mathrm{PM}_{2.5}$ measurements of particle mass and major inorganic ions measured offline by ion chromatography. Organic carbon (OC) and elemental carbon (EC) in $\mathrm{PM}_{2.5}$ were measured by an OC-EC analyzer (Sunset Labs) with a temporal resolution of $1 \mathrm{~h}$. This analyzer determined OC by thermal optical transmittance. VOCs were measured by a gas chromatography-flame ionization detector (GC-FID, Agilent Technologies) with a temporal resolution of $1 \mathrm{~h}$.

\subsection{Particle $\mathrm{pH}$ and water calculation}

The thermodynamic equilibrium model ISORROPIA II was used to determine the phase state and composition of an $\mathrm{NH}_{4}^{+}-\mathrm{SO}_{4}^{2-}-\mathrm{NO}_{3}^{-}-\mathrm{Cl}^{-}-\mathrm{Na}^{+}-\mathrm{Ca}^{2+}-\mathrm{K}^{+}-\mathrm{Mg}^{2+}$-water inorganic aerosol in equilibrium with its corresponding gasphase species (Fountoukis and Nenes, 2007; Nenes et al., 1998). This approach was used in previous studies to determine particle water and $\mathrm{pH}$ in different parts of the world (Guo et al., 2015, 2016, 2017a, c; Bougiatioti et al., 2016; Weber et al., 2016; Shi et al., 2017). The $\mathrm{pH}$ of an aqueous solution is defined as the negative logarithm of the hydronium ion $\left(\mathrm{H}_{3} \mathrm{O}^{+}\right)$activity on a molality basis (http: //www.goldbook.iupac.org/html/P/P04524.html, last access: 6 July 2018):

$\mathrm{pH}=-\log _{10}\left[a\left(\mathrm{H}^{+}\right)\right]=-\log _{10}\left[m\left(\mathrm{H}^{+}\right) \gamma_{\mathrm{m}}\left(\mathrm{H}^{+}\right) / m^{\theta}\right]$,

where $a\left(\mathrm{H}^{+}\right)$is the hydronium ion activity in an aqueous solution, $m\left(\mathrm{H}^{+}\right)$is the hydronium ion molality, $\gamma_{\mathrm{m}}\left(\mathrm{H}^{+}\right)$is the molality-based hydronium ion activity coefficient, and $m^{\theta}$ is the standard molality $\left(1 \mathrm{~mol} \mathrm{~kg}^{-1}\right)$. For simplicity, $\mathrm{H}_{3} \mathrm{O}^{+}$is denoted here as $\mathrm{H}^{+}$even though we recognize that the un-hydrated hydrogen ion is rare in aqueous solutions. Since most thermodynamic equilibrium models (e.g., ISORROPIA II, E-AIM) do not report liquid concentrations, but instead report species in terms of concentration per volume of air (e.g., $\mu \mathrm{g} \mathrm{m}^{-3}, \mu \mathrm{mol} \mathrm{m}^{-3}$ ), we have calculated the particle $\mathrm{pH}$ by

$\mathrm{pH}=-\log _{10} \gamma_{\mathrm{H}^{+}} \mathrm{H}_{\mathrm{aq}}^{+}=-\log _{10} \frac{1000 \gamma_{\mathrm{H}^{+}} \mathrm{H}_{\mathrm{air}}^{+}}{W_{\mathrm{i}}+W_{\mathrm{o}}}$

$$
\cong-\log _{10} \frac{1000 \gamma_{\mathrm{H}^{+}} \mathrm{H}_{\mathrm{air}}^{+}}{W_{\mathrm{i}}},
$$

where $\gamma_{\mathrm{H}^{+}}$is the hydronium ion activity coefficient (assumed to be 1$), \mathrm{H}_{\mathrm{aq}}^{+}$is the concentration of hydronium ions in particle water in moles per liter (i.e., the density of water is assumed to be $1000 \mathrm{~kg} \mathrm{~m}^{-3}$, and so $\mathrm{pH}$ is calculated in terms of molality), $\mathrm{H}_{\text {air }}^{+}\left(\mu \mathrm{g} \mathrm{m}^{-3}\right)$ is the hydronium ion concentration per volume of air, and $W_{\mathrm{i}}$ and $W_{\mathrm{o}}\left(\mu \mathrm{g} \mathrm{m}^{-3}\right)$ are the bulk particle water concentrations associated with inorganic and organic species per volume of air, respectively. In Eq. (1b), the molecular weight of $\mathrm{H}^{+}$is taken as $1 \mathrm{~g} \mathrm{~mole}^{-1}$, and 1000 is the factor needed for unit conversion of grams per liter to micrograms per cubic meter. $\mathrm{H}_{\text {air }}^{+}$and $W_{\mathrm{i}}$ are outputs of the ISORROPIA II model. Previous studies have shown that particle $\mathrm{pH}$ values predicted using only $W_{\mathrm{i}}$ are reasonably accurate since the sensitivity of particle $\mathrm{pH}$ to the effects of $W_{\mathrm{o}}$ is small (Guo et al., 2015). For the southeastern US, Guo et al. (2015) reported that particle $\mathrm{pH}$ values predicted using only $W_{\mathrm{i}}$ were systematically 0.15 to 0.23 units lower than those predicted using $W_{\mathrm{i}}+W_{\mathrm{o}}$ during the 2013 Southern Oxidant Aerosol Study (SOAS) and SCAPE campaigns. Given this small deviation and that organic aerosol hygroscopicity was not measured in this field study, we report particle $\mathrm{pH}$ only considering $W_{\mathrm{i}}$.

ISORROPIA II was run in "forward" mode, which assumes that aerosols are "metastable" with no solid precipitates, to predict particle $\mathrm{pH}$ and the partitioning of semivolatile compounds. In forward mode, the model calculates the gas-particle equilibrium partitioning concentrations based on the input of the total concentration of a species (i.e., gas + particle). In reverse mode, the model calculates the gas-particle equilibrium partitioning concentrations based on the input of only the particle-phase concentration of a species. We used forward mode because the reverse mode is sensitive to measurement errors, which often result in large model biases in the predicted particle $\mathrm{pH}$ (Hennigan et al., 2015). The measured particle-phase inorganic $\mathrm{NH}_{4}^{+}, \mathrm{SO}_{4}^{2-}$, and $\mathrm{NO}_{3}^{-}$concentrations and gas-phase $\mathrm{HNO}_{3}$ and $\mathrm{NH}_{3}$ concentrations were used as model inputs. The metastable assumption is reasonable since the high RH (average RH $68.9 \%$ ) observed during the study indicated that the aerosols had likely deliquesced. We excluded data for periods when the $\mathrm{RH}$ was above $95 \%$ since the exponential growth in particle liquid water with $\mathrm{RH}$ introduces large $\mathrm{pH}$ uncertainties (Malm and Day, 2001; Guo et al., 2015).

In using ISORROPIA II to predict particle $\mathrm{pH}$ and the partitioning of semi-volatile compounds, we also assumed that the aerosols are internally mixed and that the particle $\mathrm{pH}$ does not change with particle size (i.e., the overall particle $\mathrm{pH}$ is characterized by the particle's bulk properties). As long as some small fraction of sulfate is mixed with various aerosol components, (e.g., non-volatile cations), the assumption that aerosols are completely internally mixed has a small effect on the predicted pH (Guo et al., 2017b). However, the presence 
of multiple organic and inorganic species in ambient aerosols may lead to multiple phases within the particle (i.e., phase separation). Consequently, this may result in the unequal distribution of inorganic species among different phases, each with its own water activity and inorganic concentration. Previous studies have shown that liquid-liquid and solid-liquid phase separations may occur for mixed organic and inorganic aerosols at low RH and organic aerosol oxygen-to-carbon atomic ratios (O/C) (Bertram et al., 2011; Song et al., 2012; You et al., 2013, 2014b; You and Bertram, 2015). Phase separations were always observed at $\mathrm{O} / \mathrm{C} \leq 0.5$, while no phase separation was observed at $\mathrm{O} / \mathrm{C} \geq 0.8$. The probability for the occurrence of phase separation decreased at higher $\mathrm{RH}$ for $0.5<\mathrm{O} / \mathrm{C}<0.8$. The average $\mathrm{O} / \mathrm{C}$ for this field study is $0.69 \pm 0.06$. Organic acids were not included in the calculation of particle $\mathrm{pH}$. This is reasonable since their total mass concentration was small compared to the total inorganic mass concentration. The average ratio of the organic acid mass concentration to the inorganic mass concentration is 0.25. Furthermore, Song et al. (2018) showed that including organic acid mass concentrations in thermodynamic model calculations had minor effects on particle $\mathrm{pH}$ if the system is in equilibrium. The validity of these assumptions and the resulting thermodynamic model predictions will be evaluated by comparing the predicted gas-particle partitioning ratios of semi-volatile inorganic compounds with measured values in Sect. 3.3.

\section{Results and discussion}

\section{$3.1 \quad \mathrm{NH}_{3}$ observations}

Continuous measurements of $\mathrm{NH}_{3}$ were made using the $\mathrm{NH}_{3}$-CIMS from 13 September to 12 October. Figure 1a and $b$ show the time series and average diurnal profile of $\mathrm{NH}_{3}$, respectively. $\mathrm{NH}_{3}$ concentrations ranged from 0.7 to $39.0 \mathrm{ppb}\left(0.5\right.$ to $\left.28.5 \mathrm{\mu g} \mathrm{m}^{-3}\right)$ and exhibited consistent diurnal cycles. $\mathrm{NH}_{3}$ was generally higher in the late mornings and early afternoons. Concentrations started to increase at 07:30, which coincided with an increase in temperature at sunrise (Fig. S3). Possible reasons for the morning increase include volatilization of particulate ammonium and animal waste, entrainment from the residual layer where $\mathrm{NH}_{3}$ may not have been depleted, evaporation of dew or fog that contained dissolved $\mathrm{NH}_{3}$, and emission from plant stomata (Ellis et al., 2011). $\mathrm{NH}_{3}$ decreased at 14:30, approximately $1 \mathrm{~h}$ before temperature decreased, and may be due to changes in the boundary layer height. However, this hypothesis cannot be tested since the boundary layer height was not measured during the study. The diurnal plot does not account for dilution as the boundary layer expanded and only indicates that if emissions were solely from the surface and lower concentrations aloft, these $\mathrm{NH}_{3}$ sources were of significant magnitude.
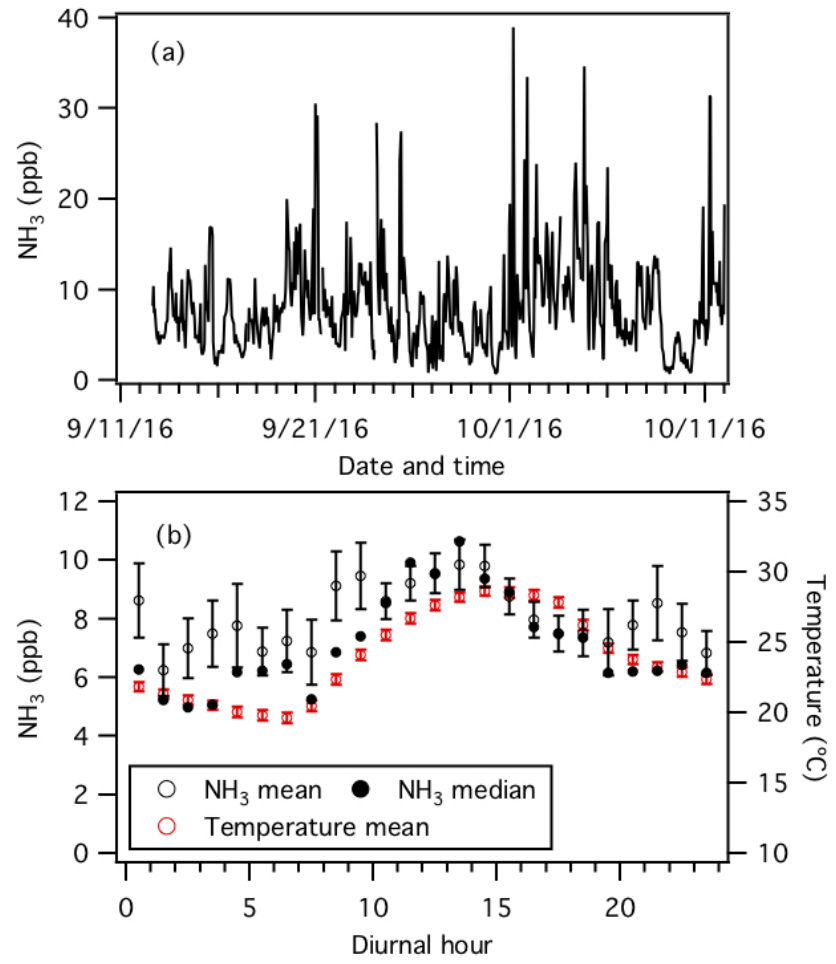

(c)

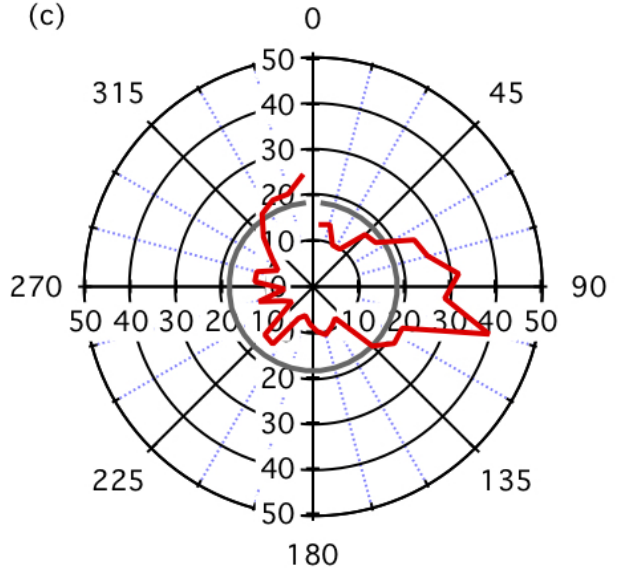

Figure 1. Measurements by the $\mathrm{NH}_{3}$-CIMS during the second half of the study. (a) Time series of $\mathrm{NH}_{3}$ concentration. The data are displayed as $1 \mathrm{~h}$ averages. (b) Diurnal profiles of $\mathrm{NH}_{3}$ concentration (mean and median) and temperature. Error bars shown are the standard errors. Dates and times displayed are local time. All the concentrations represent averages in $1 \mathrm{~h}$ intervals and the standard errors are plotted as error bars. (c) Average $\mathrm{NH}_{3}$ concentration normalized to wind speed (i.e., $\mathrm{NH}_{3}$ concentration $(\mathrm{ppb}) \times$ wind speed $\left(\mathrm{ms}^{-1}\right)$ ) in each $10^{\circ}$ bin (red line). The average normalized $\mathrm{NH}_{3}$ concentration is shown as a grey line.

The average $\mathrm{NH}_{3}$ concentration measured by the $\mathrm{NH}_{3}$ CIMS is $8.1 \pm 5.2 \mathrm{ppb}$. This is approximately 2 times higher than the average $\mathrm{NH}_{3}$ concentration $(3.8 \pm 2.9 \mathrm{ppb})$ measured by the denuder-based instrument operated by the SEARCH network over the same time period (Fig. S4). Differences in 
$\mathrm{NH}_{3}$ concentrations measured by the two instruments may be due to positive and negative sampling artifacts caused by differences in sampling inlets (e.g., inlet length and location), frequency of calibration and background measurements, and (in the case of the denuder-based instrument) possible sample contamination during chemical analysis. Discussions on how differences in measured $\mathrm{NH}_{3}$ concentrations affect $\mathrm{PM}_{1}$ $\mathrm{pH}$ predictions will be presented in Sect. 3.3. Nevertheless, there is a record of $\mathrm{NH}_{3}$ concentrations measured by the denuder-based instrument at this site since 2008. Just prior to and during this study, $\mathrm{NH}_{3}$ concentrations are generally the highest observed since 2011 (Fig. S5). These elevated $\mathrm{NH}_{3}$ concentrations may be due to sporadic biomass burning episodes caused by elevated temperatures and widespread drought across the southeastern US in 2016 (Park Williams et al., 2017; Case and Zavodsky, 2018).

The $\mathrm{NH}_{3}$-CIMS measurements are examined with the meteorological data to gain insights into the primary $\mathrm{NH}_{3}$ sources during the sampling period. To account for wind speed, the $1 \mathrm{~h}$ averaged $\mathrm{NH}_{3}$ concentrations are first multiplied by their corresponding $1 \mathrm{~h}$ averaged wind speeds. These normalized $\mathrm{NH}_{3}$ concentrations are then used to construct a wind direction polar plot showing the average normalized $\mathrm{NH}_{3}$ concentration per $10^{\circ}$ bin (Fig. 1c). The wind direction polar plot shows that the normalized $\mathrm{NH}_{3}$ is approximately 2 times greater than the average when air masses are transported from the southeast, the general direction of the poultry CAFOs located approximately $2 \mathrm{~km}$ from the field site (Fig. S1), which are known for having high $\mathrm{NH}_{3}$ emissions. This conclusion is reaffirmed by $\mathrm{NH}_{3}$ measurements from the SEARCH network's denuder-based instrument.

$\mathrm{NH}_{3}$ concentrations measured by the two instruments in this study are substantially higher than those measured in three recent field studies conducted in the continental US: the 2010 California Nexus (CalNex) study, 2013 Southeast Nexus (SENEX) study, and 2013 SOAS study (see Table 1). The differences in $\mathrm{NH}_{3}$ may be attributed to differences in land use, proximity to CAFOs, and meteorological conditions. The high $\mathrm{NH}_{3}$ concentrations in this study allow us to make ambient observations of the effect of $\mathrm{NH}_{3}$ on particle acidity and the gas-particle partitioning of semi-volatile inorganic and organic compounds, and compare them with previous studies.

\section{2 $\mathrm{PM}_{1}$ composition}

The aerosol inorganic chemical composition was measured by several instruments during this study. The HR-ToF-AMS, PILS-IC and PILS-HPIC measured the composition of PM 1 , while a filter-based particle composition monitor measured the composition of $\mathrm{PM}_{2.5}$. Comparisons of aerosol $\mathrm{SO}_{4}^{2-}$, $\mathrm{NO}_{3}^{-}$, and $\mathrm{NH}_{4}^{+}$mass concentrations obtained from the application of CDCE values to the raw HR-ToF-AMS data are compared to those measured by the other three instruments in Fig. S6. $\mathrm{NH}_{4}^{+}$measurements by the PILS-IC are not avail- able for comparison due to denuder breakthrough that occurred during the study.

$\mathrm{SO}_{4}^{2-}$ measurements by the various instruments are generally well correlated with each other, with $R^{2}$ values ranging from 0.64 to 0.92 . Although $\mathrm{PM}_{1} \mathrm{SO}_{4}^{2-}$ measurements by the two PILS systems show good agreement with each other, HR-ToF-AMS CDCE-applied $\mathrm{SO}_{4}^{2-}$ measurements are approximately 2 times higher than the PILS and filter measurements. Similar systematic differences are also observed for $\mathrm{NO}_{3}^{-}$and $\mathrm{NH}_{4}^{+}$measurements. $\mathrm{NO}_{3}^{-}$and $\mathrm{NH}_{4}^{+}$measurements from the four instruments are moderately correlated ( $R^{2}=0.54$ to 0.79 and $R^{2}=0.94$, respectively). $\mathrm{NO}_{3}^{-}$measurements from the PILS and filter systems are mostly similar; however, HR-ToF-AMS CDCE-applied $\mathrm{PM}_{1} \mathrm{NO}_{3}^{-}$and $\mathrm{NH}_{4}^{+}$measurements are approximately 3 times and 2 times higher than the PILS and filter measurements. One possible reason is that the calculated $\mathrm{CDCE}$ is lower due to organics dominating the aerosol composition during the study (average of $74.2 \pm 7.9 \%$ of the non-refractory $\mathrm{PM}_{1}$ mass concentration). Lee et al. (2015) suggested that a high organic mass fraction may impede the complete efflorescence of aerosols when they are passed through the drier prior to delivery into the HR-ToF-AMS, thus reducing the particle bounce and increasing the CE value. Hence, we estimated HR-ToF-AMS $\mathrm{PM}_{1}$ mass concentrations that would be consistent with PILS and filter measurements by multiplying all the raw HR-ToFAMS data by a constant $\mathrm{CE}$ value of 0.9 , which was obtained from comparisons of the raw HR-ToF-AMS $\mathrm{SO}_{4}^{2-}$ data with PILS-IC and PILS-HPIC SO ${ }_{4}^{2-}$ measurements. The constant CE-applied HR-ToF-AMS data are used in all our subsequent analyses.

Figure 2 shows the time series and average diurnal profiles of non-refractory $\mathrm{PM}_{1}$ species. The average non-refractory $\mathrm{PM}_{1}$ organics, $\mathrm{SO}_{4}^{2-}, \mathrm{NO}_{3}^{-}$, and $\mathrm{NH}_{4}^{+}$mass concentrations are $5.0 \pm 2.3,1.6 \pm 0.4,0.2 \pm 0.1$, and $0.4 \pm 0.2 \mu \mathrm{g} \mathrm{m}^{-3}$, respectively. Organics are the dominant non-refractory $\mathrm{PM}_{1}$ species, accounting for $74.2 \pm 7.9 \%$ of the non-refractory $\mathrm{PM}_{1}$ mass concentration during the field study. Organic aerosol mass concentration was slightly higher at night, which is likely caused by changes in the boundary layer height, emission sources, and SOA formation processes $(\mathrm{Xu}$ et al., 2015b). Previous studies have shown that nighttime SOA production in the southeastern US is largely attributed to nitrate radical oxidation and ozonolysis of monoterpenes, which are abundant at night (Pye et al., 2015; Xu et al., 2015a, b; Lee et al., 2016; Zhang et al., 2018). Specifically, the nitrate radical oxidation of some monoterpenes (e.g., $\beta$ pinene) could form low-volatility organic nitrates that are condensable and could contribute substantially to the nocturnal organic aerosol mass (Boyd et al., 2015, 2017; $\mathrm{Ng}$ et al., 2017). Apportionment of organic aerosol sources will be discussed in an upcoming publication. $\mathrm{SO}_{4}^{2-}$ is the second most abundant non-refractory $\mathrm{PM}_{1}$ species $(16.3 \pm 5.7 \%$ mass fraction), followed by $\mathrm{NH}_{4}^{+}(5.9 \pm 2 \%$ mass fraction $)$ 

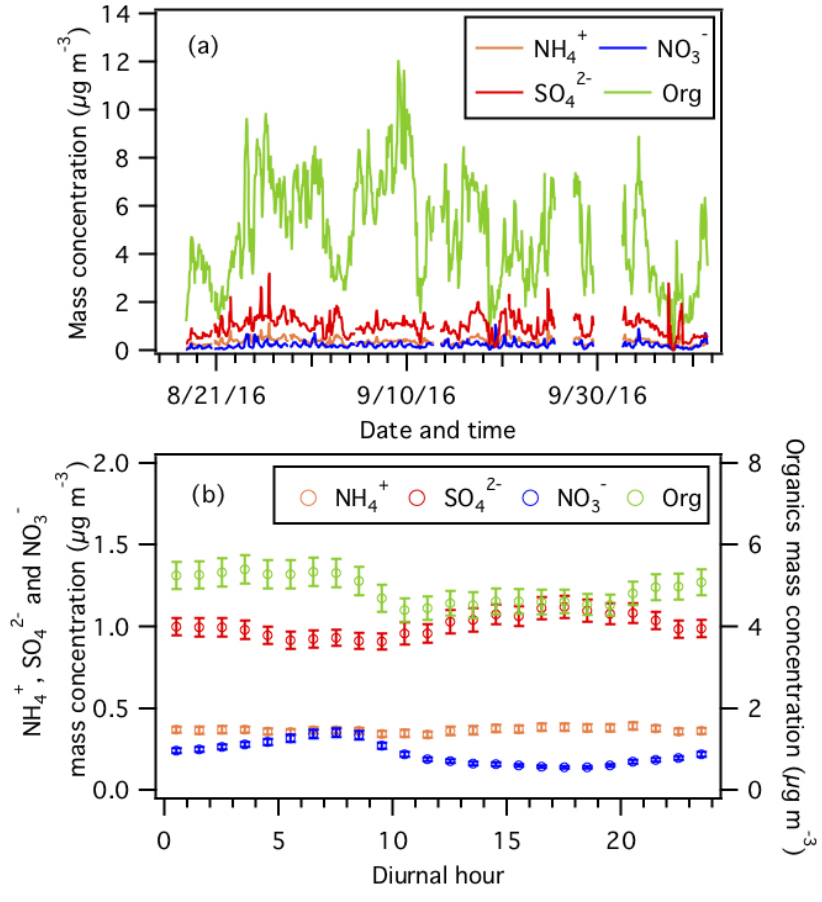

Figure 2. (a) Time series and (b) diurnal profiles of non-refractory $\mathrm{PM}_{1}$ species measured by the AMS. Error bars shown in (b) are the standard errors. Dates and times displayed are local time.

and $\mathrm{NO}_{3}^{-}\left(3.6 \pm 2.2 \%\right.$ mass fraction). $\mathrm{SO}_{4}^{2-}$ mass concentration peaked in the afternoon due to enhanced $\mathrm{SO}_{2}$ photooxidation (Weber et al., 2003). The $\mathrm{NO}_{3}^{-}$mass concentration measured by the HR-ToF-AMS is the nitrate functional group $\left(-\mathrm{ONO}_{2}\right)$ present on organic and inorganic nitrates. Hence, the diurnal profile of the $\mathrm{NO}_{3}^{-}$mass concentration in Fig. 2 has contributions from both organic and inorganic nitrates. The mass concentrations of organic and inorganic nitrates increased after sunset and peaked at sunrise (Fig. S7), likely due to the formation of organic nitrates from nighttime $\mathrm{NO}_{3}$ chemistry and increased gas-to-particle partitioning of organic and inorganic nitrates as temperature decreased (Xu et al., 2015a, b). Quantification and characterization of organic nitrates based on HR-ToF-AMS and PILS-IC $\mathrm{PM}_{1} \mathrm{NO}_{3}^{-}$measurements will be discussed in a future publication. $\mathrm{NH}_{4}^{+}$mass concentration has moderate diurnal variations with marginally higher concentrations in the afternoon, likely due to the contrasting day-night phases of ammonium sulfate and ammonium nitrate formation. $\mathrm{SO}_{4}^{2-}, \mathrm{NO}_{3}^{-}$, and $\mathrm{NH}_{4}^{+}$molar concentrations indicated that $\mathrm{NH}_{4}^{+}$is mainly associated with $\mathrm{SO}_{4}^{2-}$ in $\mathrm{PM}_{1}$.

\section{3 $\quad \mathrm{PM}_{1} \mathrm{pH}$ predictions}

CIMS $\mathrm{HNO}_{3}$ and $\mathrm{NH}_{3}$ data, HR-ToF-AMS $\mathrm{PM}_{1} \mathrm{SO}_{4}^{2-}$ and $\mathrm{NH}_{4}^{+}$data, PILS-IC $\mathrm{PM}_{1} \mathrm{NO}_{3}^{-}$and non-volatile cation $\left(\mathrm{Cl}^{-}\right.$, $\mathrm{Na}^{+}, \mathrm{Ca}^{2+}, \mathrm{K}^{+}$, and $\mathrm{Mg}^{2+}$ ) data, measured temperature, and $\mathrm{RH}$ are used as ISORROPIA II model inputs to predict $\mathrm{PM}_{1}$

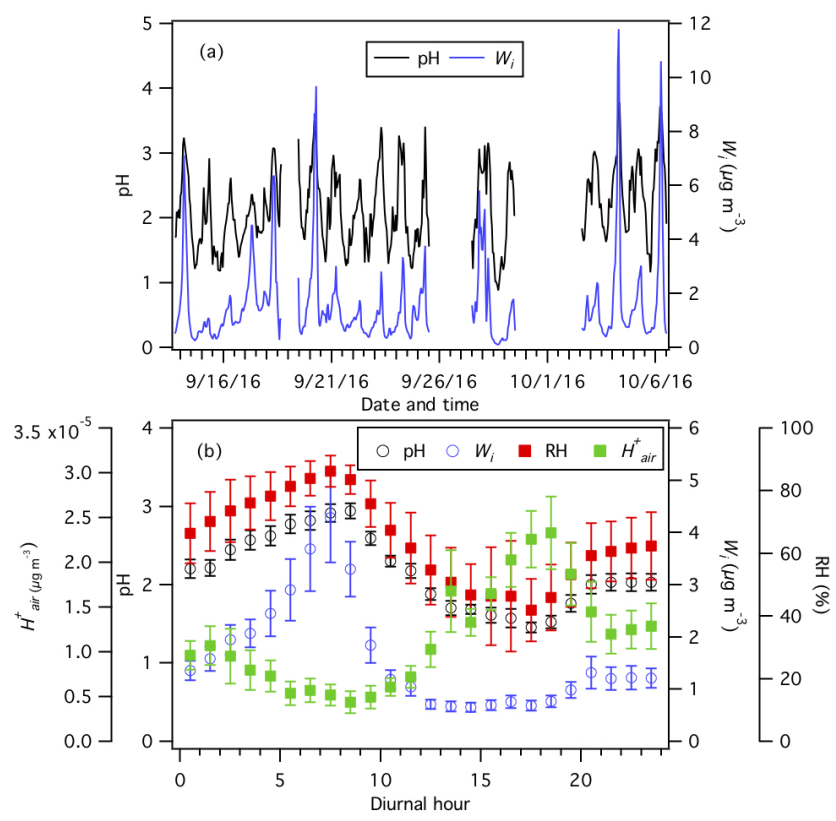

Figure 3. (a) Time series and (b) diurnal profiles of ISORROPIApredicted $\mathrm{PM}_{1} \mathrm{pH}$ and $W_{\mathrm{i}}$. The diurnal profiles of $\mathrm{RH}$ and ISORROPIA-predicted $\mathrm{H}_{\text {air }}^{+}$are also shown in (b). Dates and times displayed are local time. All the data shown here represent averages in $1 \mathrm{~h}$ intervals. Error bars shown in (b) are the standard errors.

$W_{\mathrm{i}}$ and $\mathrm{pH}$ from 13 September to 6 October. Figure 3 shows the time series and average diurnal profiles of ISORROPIApredicted $\mathrm{PM}_{1} W_{\mathrm{i}}$ and $\mathrm{pH}$. $\mathrm{PM}_{1}$ is highly acidic with $\mathrm{pH}$ values ranging from 0.9 to 3.8 and an average $\mathrm{pH}$ of $2.2 \pm 0.6$. The average $\mathrm{PM}_{1} \mathrm{pH}$ is $2.5 \pm 0.6$ during periods when the $\mathrm{NH}_{3}$ concentration is higher than $13.3 \mathrm{ppb}$ (i.e., average $\mathrm{NH}_{3}$ concentration +1 standard deviation $=8.1+5.2=13.3 \mathrm{ppb}$ ). The $\mathrm{PM}_{1} \mathrm{pH}$ values in this study are generally similar to those reported by Guo et al. (2015) at the same field site during winter 2012. Our observation that $\mathrm{PM}_{1}$ is acidic despite the high $\mathrm{NH}_{3}$ concentrations in this study is consistent with previous studies showing that particle $\mathrm{pH}$ has weak sensitivities to wide $\mathrm{NH}_{3}$ and $\mathrm{SO}_{4}^{2-}$ mass concentration ranges due to $\mathrm{pH}$ buffering caused by the partitioning of $\mathrm{NH}_{3}$ between the gas and particle phases (Weber et al., 2016; Guo et al., 2017c). This weak particle $\mathrm{pH}$ sensitivity also explains the small changes in $\mathrm{PM}_{1} \mathrm{pH}$ values (about $10 \%$ lower, Fig. S8) when $\mathrm{NH}_{3}$ measurements by the SEARCH network denuderbased instrument are used in ISORROPIA II calculations (instead of $\mathrm{NH}_{3}$-CIMS measurements).

$\mathrm{PM}_{1} \mathrm{pH}$ varied by approximately 1.4 units throughout the day. $W_{\mathrm{i}}$ has an average value of $1.6 \pm 1.7 \mu \mathrm{g} \mathrm{m}^{-3} . \mathrm{PM}_{1} W_{\mathrm{i}}$ and $\mathrm{pH}$ showed similar diurnal profiles, with both peaking in the midmorning and reaching their minima in the midafternoon. These diurnal trends are consistent with those previously reported by Guo et al. (2015) for $\mathrm{PM}_{1}$ measured during the summer and winter in different parts of the southeastern US. Also shown in Fig. $3 \mathrm{~b}$ is the diurnal profile of $\mathrm{H}_{\text {air }}^{+}$, 
Table 1. Comparisons among different field campaigns for particle $\mathrm{pH}$, major inorganic ions and gases, and meteorological conditions. All pH values were calculated using ISORROPIA II run in forward mode. These statistics were previously compiled by Guo et al. (2017a). Campaign acronyms used here stand for the California Research at the Nexus of Air Quality and Climate Change (CalNex), Southern Oxidant and Aerosol Study (SOAS), and Southeastern Nexus of Air Quality and Climate (SENEX).

\begin{tabular}{|c|c|c|c|c|c|}
\hline Campaign & \multicolumn{2}{|c|}{ CalNex } & SOAS & SENEX & This study \\
\hline Type & \multicolumn{2}{|c|}{ Ground } & Ground & Aircraft & Ground \\
\hline PM cut size & $\mathrm{PM}_{1}$ & $\mathrm{PM}_{2.5}^{\mathrm{a}}$ & $\mathrm{PM}_{1} \& \mathrm{PM}_{2.5}^{\mathrm{b}}$ & $\mathrm{PM}_{1}$ & $\mathrm{PM}_{1}$ \\
\hline Year & \multirow{3}{*}{\multicolumn{2}{|c|}{$\begin{array}{c}2010 \\
\text { (early summer) } \\
\text { SW US }\end{array}$}} & 2013 & 2013 & 2016 \\
\hline Season & & & Summer & Summer & Fall \\
\hline Region/location & & & SE US & SE US & SE US \\
\hline $\mathrm{SO}_{4}^{2-}, \mu \mathrm{g} \mathrm{m}^{-3}$ & $2.86 \pm 1.70$ & $1.88 \pm 0.69$ & $1.73 \pm 1.21$ & $2.05 \pm 0.80$ & $1.6 \pm 0.4$ \\
\hline $\mathrm{NO}_{3}^{-}, \mu \mathrm{g} \mathrm{m}^{-3}$ & $3.58 \pm 3.65$ & $3.74 \pm 1.53$ & $0.08 \pm 0.08$ & $0.28 \pm 0.09$ & $0.20 \pm 0.10$ \\
\hline $\mathrm{HNO}_{3}, \mu \mathrm{g} \mathrm{m}^{-3}$ & $6.65 \pm 7.03$ & $4.45 \pm 3.59$ & $0.36 \pm 0.14$ & $1.35 \pm 0.66$ & $0.50 \pm 0.26$ \\
\hline$\varepsilon\left(\mathrm{NO}_{3}^{-}\right)$ & $39 \pm 16 \%$ & $51 \pm 18 \%$ & $22 \pm 16 \%$ & $18 \pm 6 \%$ & $26 \pm 15 \%$ \\
\hline Total $\mathrm{NO}_{3}^{-}, \mu \mathrm{g} \mathrm{m}^{-3}$ & $10.22 \pm 9.74$ & $8.19 \pm 3.89$ & $0.45 \pm 0.26$ & $1.63 \pm 0.70$ & $0.70 \pm 0.28$ \\
\hline $\mathrm{NH}_{4}^{+}, \mu \mathrm{g} \mathrm{m}^{-3}$ & $2.06 \pm 1.67$ & $1.79 \pm 0.65$ & $0.46 \pm 0.34$ & $1.06 \pm 0.25$ & $0.40 \pm 0.20$ \\
\hline $\mathrm{NH}_{3}, \mu \mathrm{g} \mathrm{m}^{-3}$ & $1.37 \pm 0.90$ & $0.75 \pm 0.61$ & $0.39 \pm 0.25$ & $0.12 \pm 0.19$ & $5.79 \pm 3.67$ \\
\hline$\varepsilon\left(\mathrm{NH}_{4}^{+}\right)$ & $55 \pm 25 \%$ & $71 \pm 19 \%$ & $50 \pm 25 \%$ & $92 \pm 11 \%$ & $7 \pm 5 \%$ \\
\hline Total $\mathrm{NH}_{4}^{+}, \mu \mathrm{g} \mathrm{m}^{-3}$ & $3.44 \pm 1.81$ & $2.54 \pm 0.89$ & $0.78 \pm 0.50$ & $1.17 \pm 0.81$ & $6.19 \pm 3.68$ \\
\hline $\mathrm{Na}^{+}, \mu \mathrm{g} \mathrm{m}^{-3}$ & NA & $0.77 \pm 0.39$ & $0.03 \pm 0.07$ & NA & NA \\
\hline $\mathrm{Cl}^{-}, \mu \mathrm{g} \mathrm{m}^{-3}$ & NA & $0.64 \pm 0.48$ & $0.02 \pm 0.03$ & NA & $0.01 \pm 0.01$ \\
\hline $\mathrm{RH}, \%$ & $79 \pm 17$ & $87 \pm 9$ & $74 \pm 16$ & $72 \pm 9$ & $69 \pm 18$ \\
\hline$T,{ }^{\circ} \mathrm{C}$ & $18 \pm 4$ & $18 \pm 3$ & $25 \pm 3$ & $22 \pm 3$ & $24 \pm 4$ \\
\hline$W_{\mathrm{i}}, \mu \mathrm{g} \mathrm{m}^{-3}$ & $13.9 \pm 18.1$ & $29.8 \pm 20.7$ & $5.1 \pm 3.8$ & $3.2 \pm 2.8$ & $1.6 \pm 1.7$ \\
\hline $\mathrm{pH}$ & $1.9 \pm 0.5$ & $2.7 \pm 0.3$ & $0.9 \pm 0.6$ & $1.1 \pm 0.4$ & $2.2 \pm 0.6$ \\
\hline Reference & \multicolumn{2}{|c|}{ Guo et al. (2017a) } & Guo et al. (2015) & Xu et al. (2016) & This study \\
\hline
\end{tabular}

${ }^{\text {a }}$ Only during the last week of CalNex.

${ }^{\mathrm{b}} \mathrm{PM}_{2.5}$ was sampled in the first half and $\mathrm{PM}_{1}$ sampled in the second half of the study. Various parameters were similar in both cases. Crustal components were higher but are overall generally at low concentrations so the differences had minor effects. For example, $\mathrm{PM}_{2.5}$ $\mathrm{Na}^{+}$was $0.06 \pm 0.09 \mu \mathrm{g} \mathrm{m}^{-3}$ and $\mathrm{PM}_{1} \mathrm{Na}^{+}$was $0.01 \pm 0.01 \mu \mathrm{g} \mathrm{m}{ }^{-3}$. $\mathrm{NA}=$ not available.

which peaked in the midafternoon. The $W_{\mathrm{i}}$ and $\mathrm{H}_{\text {air }}^{+}$maximum / minimum ratios are comparable (6.5 and 5.3, respectively), thus indicating that the diurnal variation in particle $\mathrm{pH}$ is driven by both $W_{\mathrm{i}}$ and $\mathrm{H}_{\text {air }}^{+}$.

The average $\mathrm{PM}_{1} \mathrm{pH}$ for this study is about 1 unit higher than that for the SENEX and SOAS campaigns (Table 1) and is likely due to the much higher abundance of $\mathrm{NH}_{3}$ in this study. The average $\mathrm{NH}_{3}$ mass concentration in this study is approximately 49 times and 15 times higher than that in the SENEX and SOAS campaigns, respectively. The average $\mathrm{PM}_{1} \mathrm{pH}$ for this study is similar to that for the CalNex campaign even though the average $\mathrm{NH}_{3}$ mass concentration in this study is only approximately 4 times higher than that in the CalNex campaign (Guo et al., 2017a). This may be due, in part, to $\mathrm{PM}_{1} \mathrm{SO}_{4}^{2-}$ and $\mathrm{NO}_{3}^{-}$mass concentrations at CalNex being approximately 2 times and 18 times larger than those of this study, respectively. Aerosol inorganic $\mathrm{SO}_{4}^{2-}$ and $\mathrm{NO}_{3}^{-}$species are hygroscopic species. The much higher $\mathrm{NO}_{3}^{-}$ mass concentrations in the CalNex campaign (due, in part, to high $\mathrm{NO}_{x}$ emissions) increased particle $W_{\mathrm{i}}$ substantially, which diluted $\mathrm{H}^{+}$and raised particle $\mathrm{pH}$, resulting in more gas-to-particle partitioning of $\mathrm{NO}_{3}^{-}$, and eventually leading to $\mathrm{pH}$ levels similar to those observed in this study. This type of feedback does not happen in the southeastern US, where non-volatile $\mathrm{SO}_{4}^{2-}$ dominates the uptake of particle water. It is also possible that the higher RH and lower temperatures during the CalNex campaign (relative to this study) contributed to high particle $W_{\mathrm{i}}$, which diluted $\mathrm{H}^{+}$and raised particle $\mathrm{pH}$ levels similar to those observed in this study.

The validity of this study's thermodynamic model predictions is evaluated by comparing the predicted gasparticle partitioning ratios of semi-volatile inorganic compounds (i.e., $\mathrm{NO}_{3}^{-}$and $\mathrm{NH}_{4}^{+}$) with measured values (Fig. S9). CIMS $\mathrm{HNO}_{3}$ and $\mathrm{NH}_{3}$ data, PILS-IC $\mathrm{NO}_{3}^{-}$, and HR-ToF-AMS $\mathrm{NH}_{4}^{+}$data are used in this comparison. $\varepsilon\left(\mathrm{NO}_{3}^{-}\right)$and $\varepsilon\left(\mathrm{NH}_{4}^{+}\right)$are defined as the particle-phase molar concentration divided by the total molar concentration (gas + particle), i.e., $\varepsilon\left(\mathrm{NO}_{3}^{-}\right)=\mathrm{NO}_{3}^{-} /\left(\mathrm{HNO}_{3}+\mathrm{NO}_{3}^{-}\right)$ and $\varepsilon\left(\mathrm{NH}_{4}^{+}\right)=\mathrm{NH}_{4}^{+} /\left(\mathrm{NH}_{3}+\mathrm{NH}_{4}^{+}\right)$. Predicted $\mathrm{NH}_{3}, \mathrm{NH}_{4}^{+}$, and $\varepsilon\left(\mathrm{NH}_{4}^{+}\right)$values are generally within $10 \%$ of and are 


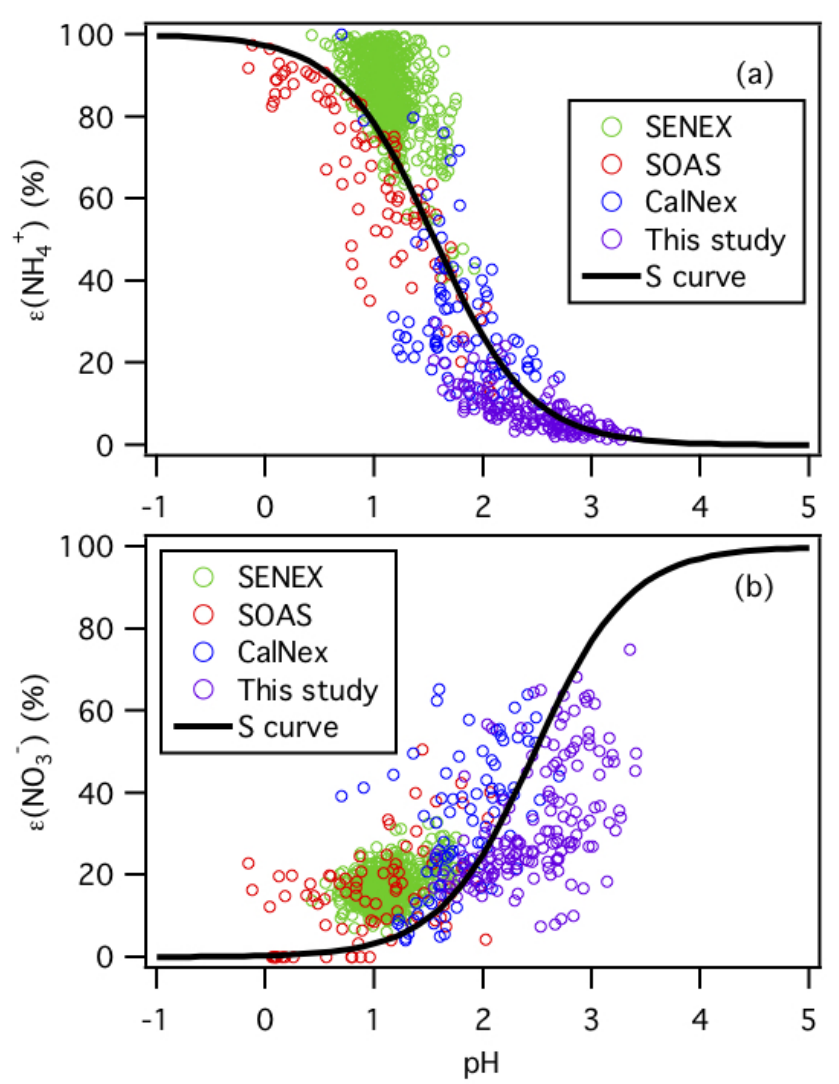

Figure 4. Analytically calculated $\mathrm{S}$ curves of $\varepsilon\left(\mathrm{NH}_{4}^{+}\right)$and $\varepsilon\left(\mathrm{NO}_{3}^{-}\right)$ and ambient data plotted against ISORROPIA-predicted particle $\mathrm{pH}$ for this study, SENEX, SOAS, and CalNex. For the ambient data sets, a narrow range of $W_{\mathrm{i}}\left(1\right.$ to $\left.4 \mu \mathrm{g} \mathrm{m}^{-3}\right)$ and temperature (15 to $25^{\circ} \mathrm{C}$ ) is selected to be close to the analytical calculation input (i.e., $W_{\mathrm{i}}=2.5 \mu \mathrm{g} \mathrm{m}^{-3}$ and temperature $=20^{\circ} \mathrm{C}$ ). Similar to Guo et al. (2017a), $\gamma_{\mathrm{NH}_{4}^{+}}=1$ and $\gamma_{\mathrm{H}^{+}-\mathrm{NO}_{3}^{-}}=\sqrt{\gamma_{\mathrm{H}^{+}} \gamma_{\mathrm{NO}_{3}^{-}}}=0.28$ are used for the analytically calculated $\mathrm{S}$ curves.

highly correlated $\left(R^{2}=0.96\right.$ to 0.99$)$ with measured values (Fig. S9). While predicted $\mathrm{HNO}_{3}$ values generally agreed with measurements, substantial scatter can be seen between the predicted and measured values for $\mathrm{NO}_{3}^{-}$and $\varepsilon\left(\mathrm{NO}_{3}^{-}\right)$. This scatter can be attributed, at least in part, to uncertainties brought about by the low $\mathrm{PM}_{1} \mathrm{NO}_{3}^{-}$mass concentrations and effects of coarse-mode cations (e.g., $\mathrm{Na}^{+}, \mathrm{Ca}^{2+}, \mathrm{K}^{+}$, and $\mathrm{Mg}^{2+}$ ) on fine-mode $\mathrm{HNO}_{3}-\mathrm{NO}_{3}^{-}$gas-particle equilibrium (i.e., $\mathrm{HNO}_{3}$ can partition to both fine and coarse modes, thereby affecting fine-mode $\mathrm{NO}_{3}^{-}$concentrations; no such effect occurs for $\mathrm{NH}_{3}-\mathrm{NH}_{4}^{+}$gas-particle equilibrium). In general, the overall good agreement between model predictions and measurements indicated that our assumptions that aerosols are metastable (i.e., aerosols are supersaturated aqueous droplets) with no phase separation for the thermodynamic calculations are reasonable for the conditions of this study and do not affect model predictions.
The molar fractions of $\mathrm{NO}_{3}^{-}$and $\mathrm{NH}_{4}^{+}$in the particle phase (i.e., $\varepsilon\left(\mathrm{NO}_{3}^{-}\right)$and $\left.\varepsilon\left(\mathrm{NH}_{4}^{+}\right)\right)$measured in this study are compared with those measured during the CalNex, SENEX, and SOAS campaigns. Figure 4 shows the measured $\varepsilon\left(\mathrm{NO}_{3}^{-}\right)$and $\varepsilon\left(\mathrm{NH}_{4}^{+}\right)$values as a function of their ISORROPIA-predicted particle $\mathrm{pH}$ for the various field studies. For each field study, only a subset of the data are chosen for this comparison $\left(1 \leq W_{\mathrm{i}} \leq 4 \mu \mathrm{g} \mathrm{m}^{-3}\right.$ and $15^{\circ} \mathrm{C} \leq$ temperature $\left.\leq 25^{\circ} \mathrm{C}\right)$ to reduce the effects of variability in $W_{\mathrm{i}}$ and temperature on gas-particle partitioning for comparison with the calculated $\mathrm{S}$ (or sigmoidal) curves, which are calculated based on $W_{\mathrm{i}}=2.5 \mathrm{\mu g} \mathrm{m}^{-3}$ and temperature $=20^{\circ} \mathrm{C}$. The $\mathrm{S}$ curves for $\mathrm{HNO}_{3}-\mathrm{NO}_{3}^{-}$and $\mathrm{NH}_{3}-\mathrm{NH}_{4}^{+}$partitioning as a function of particle $\mathrm{pH}$ are also plotted as solid lines. The $\mathrm{S}$ curves are calculated based on the solubility and dissociation of $\mathrm{NO}_{3}^{-}$ and $\mathrm{NH}_{4}^{+}$species in water:

$$
\begin{aligned}
& \varepsilon\left(\mathrm{NO}_{3}^{-}\right) \\
& =\frac{H_{\mathrm{HNO}_{3}}^{*} R T W_{\mathrm{i}} \times 0.987 \times 10^{-14}}{\gamma_{\mathrm{H}^{+}} \gamma_{\mathrm{NO}_{3}^{-}} 10^{-\mathrm{pH}}+H_{\mathrm{HNO}_{3}}^{*} R T W_{\mathrm{i}} \times 0.987 \times 10^{-14}}, \\
& \varepsilon\left(\mathrm{NH}_{4}^{+}\right)=\frac{\frac{\gamma_{\mathrm{H}^{+}} 10^{-\mathrm{pH}}}{\gamma_{\mathrm{NH}_{4}^{+}}} H_{\mathrm{NH}_{3}}^{*} R T W_{\mathrm{i}} \times 0.987 \times 10^{-14}}{1+\frac{\gamma_{\mathrm{H}^{+}} 10^{-\mathrm{pH}}}{\gamma_{\mathrm{NH}_{4}^{+}}} H_{\mathrm{NH}_{3}}^{*} R T W_{\mathrm{i}} \times 0.987 \times 10^{-14}},
\end{aligned}
$$

where $H_{\mathrm{HNO}_{3}}^{*}$ and $H_{\mathrm{NH}_{3}}^{*}\left(\right.$ mole $\left.^{2} \mathrm{~kg}^{-2} \mathrm{~atm}^{-1}\right)$ are equilibrium constants and are the products of the Henry's law constant and the dissociation constant of $\mathrm{HNO}_{3}$ and $\mathrm{NH}_{3}$, respectively; $R$ is the gas constant $\left(8.314 \mathrm{~m}^{3} \mathrm{~Pa} \mathrm{~K}^{-1} \mathrm{~mol}^{-1}\right) ; T$ is temperature $(\mathrm{K})$; and $\gamma_{i}$ 's are activity coefficients. $H_{\mathrm{HNO}_{3}}^{*}$ and $H_{\mathrm{NH}_{3}}^{*}$ values at $20^{\circ} \mathrm{C}$ are calculated using equations found in Clegg and Brimblecombe (1990) and Clegg et al. (1998), respectively. Activity coefficients predicted by ISORROPIA II are $\gamma_{\mathrm{H}^{+}-\mathrm{NO}_{3}^{-}}=\sqrt{\gamma_{\mathrm{H}^{+}} \gamma_{\mathrm{NO}_{3}^{-}}}=0.28, \gamma_{\mathrm{H}^{+}}=1$ and $\gamma_{\mathrm{NH}_{4}^{+}}=1$. Derivations of the analytically calculated $\mathrm{S}$ curves for $\varepsilon\left(\mathrm{NO}_{3}^{-}\right)$and $\varepsilon\left(\mathrm{NH}_{4}^{+}\right)$in Eqs. (2) and (3) can be found in Guo et al. (2017a). As shown in Fig. 4, the measured $\varepsilon\left(\mathrm{NO}_{3}^{-}\right)$and $\varepsilon\left(\mathrm{NH}_{4}^{+}\right)$values for the four field studies all generally converged on the calculated $\mathrm{S}$ curves. The higher particle $\mathrm{pH}$ values in this study and the CalNex campaign relative to those for the SENEX and SOAS campaigns resulted in less $\mathrm{NH}_{3}$ and more $\mathrm{HNO}_{3}$ partitioned to the particle phase, as predicted by these simple analytical expressions. A similar analysis will be performed for the organic acids in Sect. 3.5.

\subsection{WSOC and water-soluble organic acids}

The time series and average diurnal profiles of $\mathrm{WSOC}_{\mathrm{g}}$ and $\mathrm{WSOC}_{\mathrm{p}}$ are shown in Fig. S10. The average $\mathrm{WSOC}_{\mathrm{g}}$ mass concentration $\left(3.6 \pm 2.7 \mu \mathrm{g} \mathrm{C} \mathrm{m}^{-3}\right)$ is roughly 4 times higher than that of $\mathrm{WSOC}_{\mathrm{p}}\left(1.0 \pm 0.6 \mu \mathrm{g} \mathrm{Cm}{ }^{-3}\right)$. The diurnal profile of $\mathrm{WSOC}_{\mathrm{p}}$ is somewhat flat, likely due to various organic aerosol sources having different water solubility and diurnal cycles and compensating for each other throughout 

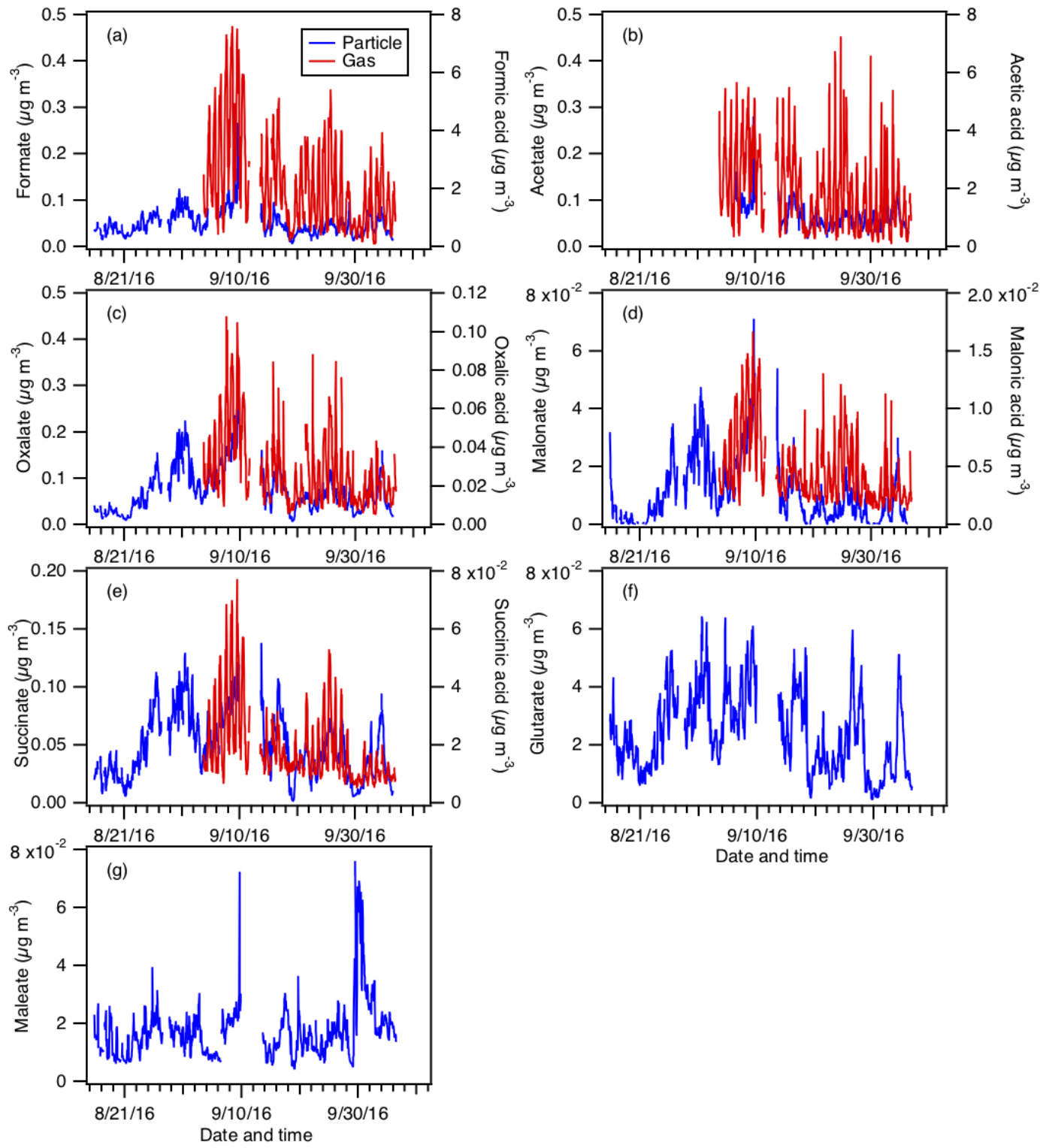

Figure 5. Particle- and gas-phase measurements of (a) formic, (b) acetic, (c) oxalic, (d) malonic, (e) succinic, (f) glutaric, and (g) maleic acids. Particle-phase measurements are shown on the left $y$ axes, while gas-phase measurements are shown on the right $y$ axes. Dates and times displayed are local time. Gas-phase measurements of glutaric and maleic acids are not available.

the day (Xu et al., 2015b, 2017). In contrast, $\mathrm{WSOC}_{\mathrm{g}}$ displayed strong diurnal variations. $\mathrm{WSOC}_{\mathrm{g}}$ increased at 07:30, which coincided with the sharp increase in solar irradiance (Fig. S3). WSOC $_{\mathrm{g}}$ decreased at 21:30, approximately $2 \mathrm{~h}$ after sunset. Also shown in Fig. S10 are the time series and average diurnal profile of the mass fraction of total WSOC in the particle phase, i.e., $F_{\mathrm{p}}=\mathrm{WSOC}_{\mathrm{p}} /\left(\mathrm{WSOC}_{\mathrm{p}}+\mathrm{WSOC}_{\mathrm{g}}\right)$. The peak $F_{\mathrm{p}}$ coincided with the minima of $\mathrm{WSOC}_{\mathrm{g}}$ at 07:30.

The average $\mathrm{WSOC}_{\mathrm{g}}$ and $\mathrm{WSOC}_{\mathrm{p}}\left(3.6 \pm 2.7 \mu \mathrm{g} \mathrm{C} \mathrm{m}{ }^{-3}\right.$ and $1.0 \pm 0.6 \mu \mathrm{g} \mathrm{Cm}^{-3}$ ) are slightly lower than those measured during the SOAS campaign (SOAS WSOC $\mathrm{g}=4.9 \mu \mathrm{g} \mathrm{Cm}{ }^{-3}$ and $\mathrm{WSOC}_{\mathrm{p}}=1.7 \mu \mathrm{g} \mathrm{Cm}^{-3}$ ) (Xu et al., 2017). While the di- urnal profiles of $\mathrm{WSOC}_{\mathrm{p}}$ in both studies are flat, the diurnal profiles of $\mathrm{WSOC}_{\mathrm{g}}$ measured in the two studies are different. $\mathrm{WSOC}_{\mathrm{g}}$ measured in the SOAS study decreased at sunset, while $\mathrm{WSOC}_{\mathrm{g}}$ measured in this study decreased $2 \mathrm{~h}$ after sunset. Differences in $\mathrm{WSOC}_{\mathrm{g}}$ diurnal profiles in the two studies are likely due to differences in emission sources as a result of different sampling periods (SOAS was in early summer and this study was in early fall), land use, and/or land cover. The ratio of $\mathrm{WSOC}_{\mathrm{p}}$ to $\mathrm{OC}$ for this study was estimated at $30 \%$, but this comparison is imprecise because $\mathrm{WSOC}_{\mathrm{p}}$ was $\mathrm{PM}_{1}$ and $\mathrm{OC}$ was $\mathrm{PM}_{2.5}$ (refer to Fig. S11 and Supplement Sect. S2) 

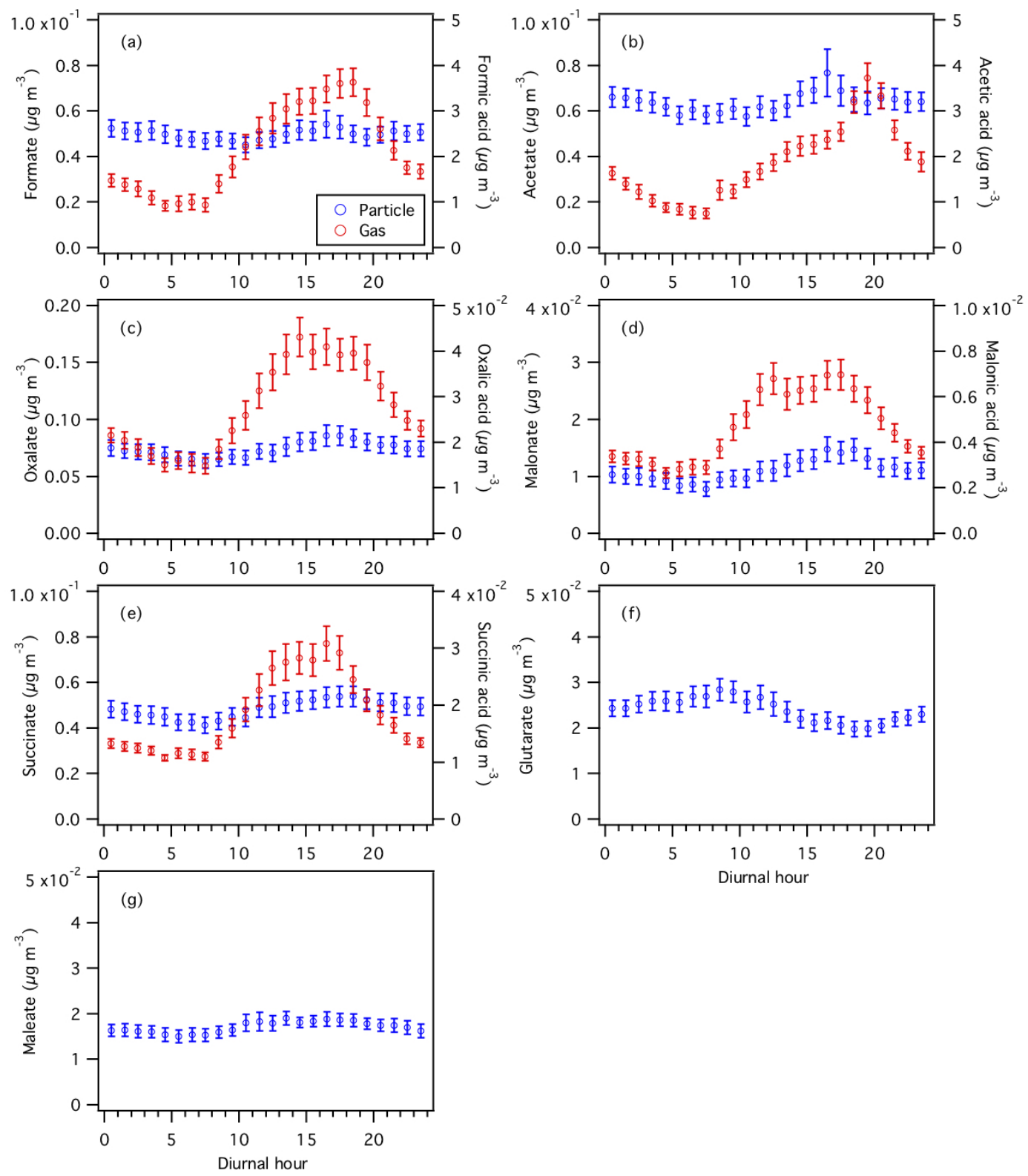

Figure 6. Diurnal profiles of particle- and gas-phase (a) formic, (b) acetic, (c) oxalic, (d) malonic, (e) succinic, (f) glutaric, and (g) maleic acids. Particle-phase measurements are shown on the left $y$ axes, while gas-phase measurements are shown on the right $y$ axes. All the data shown here represent averages in $1 \mathrm{~h}$ intervals. Error bars shown are the standard errors.

Figure 5 shows the time series of particle- and gas-phase concentrations of formic, acetic, oxalic, malonic, succinic, glutaric, and maleic acids. Their diurnal profiles are shown in Fig. 6. Gas-phase measurements of glutaric and maleic acids are not available. Gas-phase measurements of butyric, glycolic, propionic, and valeric acids were also measured during the study and have been presented in Nah et al. (2018), but will not be discussed here since their particle-phase measurements are not available.

Assuming that all the measured organic acids are completely water soluble, $30 \%$ of the $\mathrm{WSOC}_{\mathrm{g}}$ is comprised of these organic acids (Nah et al., 2018). Formic and acetic acids are the most abundant gas-phase organic acids, with av-

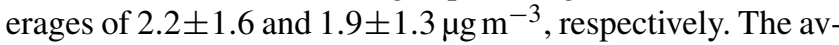
erage carbon mass fraction of $\mathrm{WSOC}_{\mathrm{g}}$ comprised of formic and acetic acids is $7 \%$ and $13 \%$, respectively. All the gasphase organic acids displayed strong and consistent diurnal cycles, with higher concentrations being measured during warm and sunny days. Their concentrations start to increase at sunrise (at 07:30), building to a peak between 15:30 and 19:30, then decrease overnight. 
Nah et al. (2018) previously showed that the measured gasphase organic acids during the study, including oxalic acid, likely have the same or similar sources. Poor correlations between gas-phase organic acid concentrations and those of anthropogenic pollutants $\left(\mathrm{HNO}_{3}, \mathrm{SO}_{2}, \mathrm{CO}\right.$, and $\left.\mathrm{O}_{3}\right)$ indicated that these organic acids are not due to anthropogenic emissions and are likely biogenic in nature. Biogenic emissions of gas-phase organic acids and/or their BVOC precursors are elevated at high temperatures, resulting in higher organic acid concentrations during warm and sunny days. For example, isoprene, which is the dominant BVOC in Yorkville, has a somewhat similar diurnal profile to the organic acids. In addition, the concentration of isoprene is moderately correlated with those of formic and acetic acids (Fig. S10 of Nah et al., 2018), which are known products of isoprene photooxidation. Some of these gas-phase organic acids may also be formed in the particle phase during organic aerosol photochemical aging, with subsequent volatilization into the gas phase. The gas-particle partitioning of organic acids likely depends on thermodynamic conditions, which are controlled by particle $\mathrm{pH}$ and $W_{\mathrm{i}}$ and meteorological conditions, as will be shown in Sect. 3.5.

The measured particle-phase water-soluble organic acids contributed on average $6 \%$ to the HR-ToF-AMS-measured organic aerosol mass concentration. The average carbon mass fraction of $\mathrm{WSOC}_{\mathrm{p}}$ comprised of these organic acids is $4 \%$. Previous studies have shown that particle-phase organic acids found in rural environments are oxidation products of gas-phase aliphatic monocarboxylic acids, which are formed in the photochemical oxidation of biogenic unsaturated fatty acids and other BVOC precursors (Kawamura and Gagosian, 1987; Kawamura and Ikushima, 1993; Kerminen et al., 2000; Kawamura and Bikkina, 2016). These particlephase organic acids can also be produced during the multiphase photochemical aging of ambient organic aerosols (Ervens et al., 2004; Lim et al., 2005; Sorooshian et al., 2007, 2010).

Oxalate is the most abundant measured particle-phase water-soluble organic acid anion (contributing on average $26 \%$ to the total particle-phase organic acid mass concentration), with mass concentrations ranging from 0.01 to $0.34 \mu \mathrm{g} \mathrm{m}^{-3}$ and an average of $0.07 \pm 0.05 \mu \mathrm{g} \mathrm{m}^{-3}$. Acetate (average of $0.06 \pm 0.03 \mu \mathrm{g} \mathrm{m}^{-3}$ ) and formate (average of $0.05 \pm 0.03 \mu \mathrm{g} \mathrm{m}^{-3}$ ) are the second and third most abundant measured particle-phase water-soluble organic acid anions, respectively. Particle-phase formate, acetate, and maleate showed weak diurnal variations, and may be due, in part, to various emission sources having different diurnal cycles and compensating for each other throughout the day. Particlephase oxalate, malonate, and succinate peaked in the middle to late afternoon, while glutarate generally peaked in the midmorning. This suggests that while the production of these organic acids is photochemically driven, they may have different BVOC precursors and/or different photochemical production pathways. In addition, since oxalic $\left(\mathrm{C}_{2}\right)$, malonic
$\left(\mathrm{C}_{3}\right)$, succinic $\left(\mathrm{C}_{4}\right)$, and glutaric $\left(\mathrm{C}_{5}\right)$ acids belong to the same homologous series of organic diacids, it is possible that the photochemical aging of particle-phase glutaric acid resulted in the formation of its successive homologues via the cleavage of $\mathrm{C}-\mathrm{C}$ bonds. Hence, organic aerosol photochemical aging may also have contributed to the diurnal profiles of particle-phase oxalate, malonate, succinate, and glutarate.

\subsection{Gas-particle partitioning of organic acids}

The online and simultaneous measurements of gas- and particle-phase organic acid mass concentrations provided the opportunity to study gas-particle partitioning behavior of semi-volatile organic compounds with respect to particle $\mathrm{pH}$, as is more commonly done with semi-volatile inorganic species (see Sect. 3.3). Since formic, acetic, and oxalic acids are the three most abundant measured organic acids present in the gas and particle phases, we focus on the gas-particle partitioning behaviors of these three organic acids. The average molar fractions ( \pm 1 standard deviation) of formic, acetic, and oxalic acid in the particle phase (i.e., $\varepsilon\left(\mathrm{HCOO}^{-}\right)$, $\varepsilon\left(\mathrm{CH}_{3} \mathrm{CO}_{2}^{-}\right)$, and $\left.\varepsilon\left(\mathrm{C}_{2} \mathrm{O}_{4}^{2-}\right)\right)$ are $3.6 \pm 3.6 \%, 5.8 \pm 5.0 \%$, and $73.7 \pm 9.8 \%$, respectively. The uncertainties of these ratios for formic, acetic, and oxalic acids are $16 \%, 16 \%$, and $17 \%$, respectively, which are obtained from the propagation of their $\mathrm{SF}_{6}$-CIMS and PILS-HPIC measurement uncertainties.

\subsubsection{Oxalic acid}

To investigate the factors affecting oxalic acid gas-particle partitioning, the equation for the $S$ curve describing the dependence of oxalic acid gas-particle partitioning (i.e., $\left.\varepsilon\left(\mathrm{C}_{2} \mathrm{O}_{4}^{2-}\right)=\mathrm{C}_{2} \mathrm{O}_{4}^{2-} /\left(\mathrm{C}_{2} \mathrm{H}_{2} \mathrm{O}_{4}+\mathrm{C}_{2} \mathrm{O}_{4}^{2-}\right)\right)$ on particle $\mathrm{pH}$ is derived. As shown in Supplement Sect. S3, the analytically calculated $\mathrm{S}$ curve for $\varepsilon\left(\mathrm{C}_{2} \mathrm{O}_{4}^{2-}\right)$ can be simplified to

$$
\varepsilon\left(\mathrm{C}_{2} \mathrm{O}_{4}^{2-}\right) \cong \frac{\left.H_{\mathrm{C}_{2} \mathrm{H}_{2} \mathrm{O}_{4} W_{i} R T} \cong \frac{\gamma_{\mathrm{H}^{+} \gamma_{\mathrm{C}_{2} \mathrm{HO}_{4}^{-}}}}{\gamma_{C_{2} \mathrm{H}_{2} \mathrm{O}_{4}}} 10^{-\mathrm{pH}}+K_{\mathrm{a} 1}\right)}{\times 0.987 \times 10^{-14}}
$$

where $H_{\mathrm{C}_{2} \mathrm{H}_{2} \mathrm{O}_{4}}$ (mole $\left.\mathrm{L}^{-1} \mathrm{~atm}^{-1}\right)$ is the Henry's law constant for oxalic acid, $K_{\mathrm{a} 1}\left(\mathrm{~mole}^{-1}\right)$ is the first acid dissociation constant for oxalic acid, $R$ is the gas constant $\left(8.314 \mathrm{~m}^{3} \mathrm{~Pa} \mathrm{~K}^{-1} \mathrm{~mol}^{-1}\right), T$ is temperature $(\mathrm{K})$, and $\gamma_{i}$ 's are activity coefficients. We used the web version of AIOMFAC (http://www.aiomfac.caltech.edu, last access: 6 December 2017) (Zuend et al., 2008, 2011, 2012) to compute an average $\gamma_{\mathrm{C}_{2} \mathrm{H}_{2} \mathrm{O}_{4}}$ value of 0.0492. Since AIOMFAC does not predict $\gamma_{\mathrm{H}^{+}} \gamma_{\mathrm{C}_{2} \mathrm{HO}_{4}^{-}}$, we assumed that $\gamma_{\mathrm{H}^{+}} \gamma_{\mathrm{C}_{2} \mathrm{HO}_{4}^{-}}=$ $\gamma_{\mathrm{H}^{+}} \gamma_{\mathrm{NO}_{3}^{-}}$and used the ISORROPIA-predicted $\gamma_{\mathrm{H}^{+}} \gamma_{\mathrm{NO}_{3}^{-}}$ value of 0.07 . We used the average of $H_{\mathrm{C}_{2} \mathrm{H}_{2} \mathrm{O}_{4}}$ values provided by Clegg et al. (1996), Compernolle and 
Müller (2014), and Saxena and Hildemann (1996) $(6.11 \times$ $10^{8} \mathrm{~mole}^{-1} \mathrm{~atm}^{-1}$ at $25^{\circ} \mathrm{C}$ ) and accounted for the effect of temperature using Eq. (19) in Sander (2015). Although $K_{\mathrm{a} 1}$ also depends on temperature, we used the $K_{\mathrm{a} 1}$ value at $25^{\circ} \mathrm{C}\left(5.62 \times 10^{-2} \mathrm{~mole}^{-1}\right.$, Haynes, 2014) for all the oxalic acid $\mathrm{S}$ curve calculations since equations that compute $K_{\mathrm{a} 1}$ values for pure aqueous oxalic acid solutions at different temperatures are not available in the literature. In addition, the temperatures observed in this study were close to $25^{\circ} \mathrm{C}$ (study-average temperature $=23.4 \pm 4.0^{\circ} \mathrm{C}$ ).

Different $\mathrm{S}$ curves for $\varepsilon\left(\mathrm{C}_{2} \mathrm{O}_{4}^{2-}\right)$ are calculated using $1 \mathrm{~h}$ average values obtained from the diurnal profiles of temperature and $W_{\mathrm{i}}$ (specifically at 00:30, 06:30, and 12:30). The shape of the $\mathrm{S}$ curve changes with the time of day due to the diurnal variations in temperature and $W_{\mathrm{i}}$ (Fig. S12 and Supplement Sect. S3). The S curves for $\varepsilon\left(\mathrm{C}_{2} \mathrm{O}_{4}^{2-}\right)$ are very different from those of other acids, such as $\varepsilon\left(\mathrm{NO}_{3}^{-}\right)$ (shown in Fig. 4b). From the $\mathrm{S}$ curves for $\varepsilon\left(\mathrm{C}_{2} \mathrm{O}_{4}^{2-}\right)$, which are calculated using conditions in this study, some molar fraction of oxalic acid is always expected to be present in the particle phase, even at low particle $\mathrm{pH}$ (i.e., the $\mathrm{S}$ curve does not go to zero at low $\mathrm{pH}$ ). In contrast, $\mathrm{HNO}_{3}$ is expected to be present primarily in the gas phase at low particle $\mathrm{pH}$ (i.e., $\mathrm{pH}<1$ ) under similar temperature and $W_{\mathrm{i}}$ conditions. This is due primarily to differences in the Henry's law constants for the two acids. $\mathrm{H}_{\mathrm{HNO}_{3}}(2.57 \times$ $10^{5} \mathrm{~mole}^{-1} \mathrm{~atm}^{-1}$ ) at $23.4^{\circ} \mathrm{C}$ is 3 orders of magnitude smaller than $H_{\mathrm{C}_{2} \mathrm{H}_{2} \mathrm{O}_{4}}\left(7.27 \times 10^{8} \mathrm{moleL}^{-1} \mathrm{~atm}^{-1}\right)(\mathrm{Clegg}$ and Brimblecombe, 1990; Sander, 2015). This means that some undissociated form of oxalate can be found in the particle phase at any $\mathrm{pH}$, and the molar fraction of this form increases with particle $W_{\mathrm{i}}$ (see Fig. S12). Oxalic acid's very high Henry's law constant combined with the $W_{\mathrm{i}}$ conditions in this study ensures that some fraction of the organic acid will be in the particle phase regardless of the particle $\mathrm{pH}$.

Figure 7 compares the measured $\varepsilon\left(\mathrm{C}_{2} \mathrm{O}_{4}^{2-}\right)$ vs. ISORROPIA-predicted $\mathrm{PM}_{1} \mathrm{pH}$ to the analytically calculated $\mathrm{S}$ curve(s). The $\mathrm{S}$ curve is calculated based on the average temperature and $W_{\mathrm{i}}$ from 13 September to 6 October $\left(23.4 \pm 4.0^{\circ} \mathrm{C}\right.$ and $1.6 \pm 1.7 \mu \mathrm{g} \mathrm{m}^{-3}$, respectively). We also calculated the "upper" and "lower" bounds of this $\mathrm{S}$ curve based on 1 standard deviation from the average temperature and average $W_{\mathrm{i}}$. A temperature $=27.4{ }^{\circ} \mathrm{C}$ and $W_{\mathrm{i}}=0.5 \mu \mathrm{g} \mathrm{m}^{-3}$ are used for calculations of the lower bound, while a temperature $=19.4^{\circ} \mathrm{C}$ and $W_{\mathrm{i}}=3.3 \mu \mathrm{g} \mathrm{m}{ }^{-3}$ are used for calculations of the upper bound. For the ambient data, a range in $W_{\mathrm{i}}\left(0.5\right.$ to $\left.4 \mu \mathrm{g} \mathrm{m}^{-3}\right)$ and temperature (15 to $31^{\circ} \mathrm{C}$ ) is chosen to be close to the analytical calculation. As shown in Fig. 7, the measured $\varepsilon\left(\mathrm{C}_{2} \mathrm{O}_{4}^{2-}\right)$ generally converged around the $\mathrm{S}$ curve calculated using the average temperature and $W_{\mathrm{i}}$ values. Although there is some scatter, the measured ratios are mostly within the upper and lower bounds of the $\mathrm{S}$ curve.

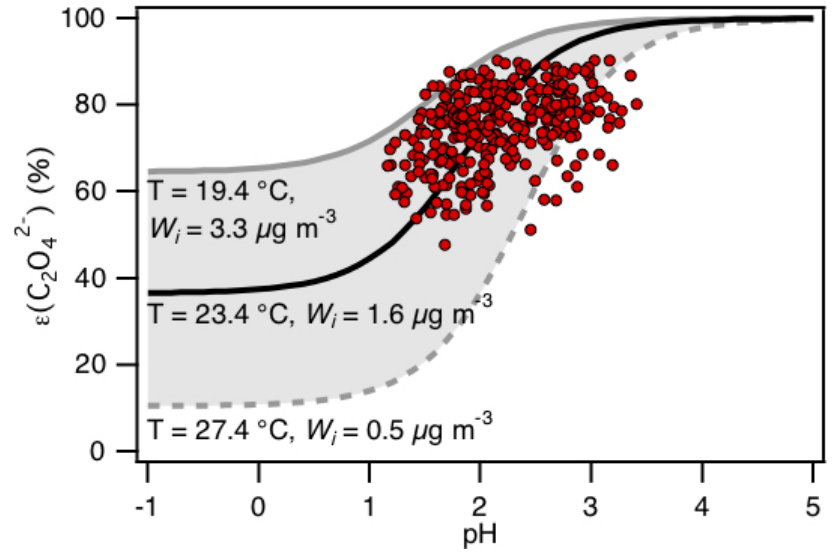

Figure 7. Analytically calculated $\mathrm{S}$ curve of $\varepsilon\left(\mathrm{C}_{2} \mathrm{O}_{4}^{2-}\right)$ and ambient data from 13 September to 6 October 2016 plotted against ISORROPIA-predicted particle $\mathrm{pH}$. For the ambient data, a range in $W_{\mathrm{i}}\left(0.5\right.$ to $\left.4 \mu \mathrm{g} \mathrm{m}^{-3}\right)$ and temperature $\left(15\right.$ to $\left.31^{\circ} \mathrm{C}\right)$ is chosen to be close to the analytically calculated outputs. For the analytically calculated $\mathrm{S}$ curves, we used $\gamma_{\mathrm{C}_{2} \mathrm{H}_{2} \mathrm{O}_{4}}=0.0492$ (AIOMFAC predicted). We also assumed that $\gamma_{\mathrm{H}^{+}} \gamma_{\mathrm{C}_{2} \mathrm{HO}_{4}^{-}}=\gamma_{\mathrm{H}^{+}} \gamma_{\mathrm{NO}_{3}^{-}}$and used the ISORROPIA-predicted $\gamma_{\mathrm{H}^{+}-\mathrm{NO}_{3}^{-}}=\sqrt{\gamma_{\mathrm{H}^{+}} \gamma_{\mathrm{NO}_{3}^{-}}}=0.265$. The black line is the $\mathrm{S}$ curve calculated using the selected time period's average temperature $\left(23.4 \pm 4.0^{\circ} \mathrm{C}\right)$ and $W_{\mathrm{i}}\left(1.6 \pm 1.7 \mu \mathrm{g} \mathrm{m}^{-3}\right)$. The grey lines are $\mathrm{S}$ curves calculated using 1 standard deviation from the average temperature and $W_{\mathrm{i}}$ (i.e., temperature $=27.4^{\circ} \mathrm{C}$ and $W_{\mathrm{i}}=0.5 \mu \mathrm{g} \mathrm{m}^{-3}$ for dotted grey line; temperature $=19.4^{\circ} \mathrm{C}$ and $W_{\mathrm{i}}=3.3 \mu \mathrm{g} \mathrm{m}^{-3}$ for solid grey line).

Since the measured $\varepsilon\left(\mathrm{C}_{2} \mathrm{O}_{4}^{2-}\right)$ values are in general agreement with the analytically calculated $\mathrm{S}$ curve (Fig. 7), we can use the $\mathrm{S}$ curve to understand qualitatively how high $\mathrm{NH}_{3}$ events at the site affect oxalic acid gas-particle partitioning. Here we define high $\mathrm{NH}_{3}$ events as periods when the $\mathrm{NH}_{3}$ concentration was higher than $13.3 \mathrm{ppb}$ (which is the average $\mathrm{NH}_{3}$ concentration +1 standard deviation). As discussed in Sect. 3.3, the $\mathrm{PM}_{1} \mathrm{pH}$ during high $\mathrm{NH}_{3}$ events is $2.5 \pm 0.6$, which is slightly higher than the average $\mathrm{PM}_{1} \mathrm{pH}$ of $2.2 \pm 0.6$. Based on the $\mathrm{S}$ curve calculated using the average temperature and $W_{\mathrm{i}}$ values, $\varepsilon\left(\mathrm{C}_{2} \mathrm{O}_{4}^{2-}\right)$ increases from $81 \%$ to $89 \%$ when particle $\mathrm{pH}$ increases from 2.2 to 2.5 . While this result indicates that high $\mathrm{NH}_{3}$ concentrations can raise the particle $\mathrm{pH}$ sufficiently such that it can promote gas-to-particle partitioning of oxalic acid, this is not always the case. Specifically, increasing the particle $\mathrm{pH}$ from -2 (or lower) to 1 will not result in a significant increase in $\varepsilon\left(\mathrm{C}_{2} \mathrm{O}_{4}^{2-}\right)$. Therefore, whether or not particle $\mathrm{pH}$, and consequently oxalic acid gas-particle partitioning, is sensitive to $\mathrm{NH}_{3}$ concentration depends strongly on particle $\mathrm{pH}$ values.

We also examined how well the analytically calculated $\mathrm{S}$ curve for $\varepsilon\left(\mathrm{C}_{2} \mathrm{O}_{4}^{2-}\right)$ captures diurnal variations in the measured $\varepsilon\left(\mathrm{C}_{2} \mathrm{O}_{4}^{2-}\right)$. The ambient data are divided into two $12 \mathrm{~h}$ sets (08:00 to 19:59 and 20:00 to 07:59) based on the diurnal profile of solar irradiance. Two $\mathrm{S}$ curves and their cor- 
responding upper and lower bounds are calculated based on the average temperature and $W_{\mathrm{i}}$ of the two data sets and are subsequently compared to the ambient data. As shown in Fig. S13, the measured $\varepsilon\left(\mathrm{C}_{2} \mathrm{O}_{4}^{2-}\right)$ values in both data sets are generally consistent with predicted values.

A number of inferences can be drawn from the overall good agreement between the predicted and measured molar fractions of oxalic acid in the particle phase in Figs. 7 and S13. Our assumptions regarding the activity coefficients, Henry's law constant, and acid dissociation constants used in the $\mathrm{S}$ curve calculations of $\varepsilon\left(\mathrm{C}_{2} \mathrm{O}_{4}^{2-}\right)$ are reasonable for the conditions of this study (or are at least self-consistent). Analytically calculated S curves are a simple way of exploring how the gas-particle partitioning of semi-volatile inorganic and organic compounds in the atmosphere are affected by the compound's physicochemical properties (e.g., Henry's law constants and acid dissociation constants), temperature, $W_{\mathrm{i}}$, and $\mathrm{pH}$. Overall, these results indicate that particle-phase oxalate is in equilibrium with gas-phase oxalic acid and that particle $\mathrm{pH}$ can influence particle-phase oxalate concentrations. It also showed that particle-phase oxalate can be found over a broad $\mathrm{pH}$ range and that the presence of oxalate does not necessarily provide insights into the particle $\mathrm{pH}$. Because of its high Henry's law constant, particle-phase oxalate can be found in aerosols even at extremely low $\mathrm{pH}$ values (i.e., the flat region in Fig. 7), although our data cannot be used to test this since ambient particle $\mathrm{pH}$ values in this study are too high.

\subsubsection{Formic and acetic acids}

Similar comparisons between the predicted and measured $\varepsilon\left(\mathrm{HCOO}^{-}\right)$and $\varepsilon\left(\mathrm{CH}_{3} \mathrm{CO}_{2}^{-}\right)$can also be made. Derivation of the equations for $\mathrm{S}$ curves describing the dependence of formic and acetic acid gas-particle partitioning (i.e., $\varepsilon\left(\mathrm{HCOO}^{-}\right)=\mathrm{HCOO}^{-} /\left(\mathrm{HCOOH}+\mathrm{HCOO}^{-}\right)$and $\varepsilon\left(\mathrm{CH}_{3} \mathrm{CO}_{2}^{-}\right)=\mathrm{CH}_{3} \mathrm{CO}_{2}^{-} /\left(\mathrm{CH}_{3} \mathrm{CO}_{2} \mathrm{H}+\mathrm{CH}_{3} \mathrm{CO}_{2}^{-}\right)$, respectively) on particle $\mathrm{pH}$ are similar to that of $\mathrm{HNO}_{3}$ since they are monoprotic acids:

$$
\begin{aligned}
& H_{\mathrm{HCOOH}} W_{\mathrm{i}} R T\left(\frac{\gamma_{\mathrm{H}^{+}} \gamma_{\mathrm{HCOO}^{-}}}{\gamma_{\mathrm{HCOOH}}} 10^{-\mathrm{pH}}+K_{\mathrm{a} 1}\right) \\
& \varepsilon\left(\mathrm{HCOO}^{-}\right)=\frac{\times 0.987 \times 10^{-14}}{\gamma_{\mathrm{H}^{+}} \gamma_{\mathrm{HCOO}^{-}} 10^{-\mathrm{pH}}+H_{\mathrm{HCOOH}} W_{\mathrm{i}} R T}, \\
& \left(\frac{\gamma_{\mathrm{H}^{+}} \gamma_{\mathrm{HCOO}}}{\gamma_{\mathrm{HCOOH}}} 10^{-\mathrm{pH}}+K_{\mathrm{al}}\right) \times 0.987 \times 10^{-14}
\end{aligned}
$$

$$
\begin{aligned}
& H_{\mathrm{CH}_{3} \mathrm{CO}_{2} \mathrm{H}} W_{\mathrm{i}} R T\left(\frac{\gamma_{\mathrm{H}^{+}} \gamma_{\mathrm{CH}_{3} \mathrm{CO}_{2}^{-}}}{\gamma_{\mathrm{CH}_{3} \mathrm{CO}_{2} \mathrm{H}}} 10^{-\mathrm{pH}}+K_{\mathrm{a} 1}\right)
\end{aligned}
$$

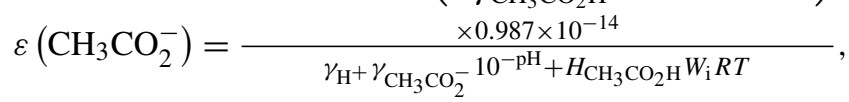

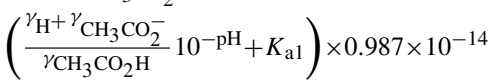

where $H_{\mathrm{HCOOH}}$ and $H_{\mathrm{CH}_{3} \mathrm{CO}_{2} \mathrm{H}}\left(\right.$ mole L $\left.^{-1} \mathrm{~atm}^{-1}\right)$ are the Henry's law constants for formic and acetic acid, $K_{\mathrm{a} 1}$ 's (mole $\mathrm{L}^{-1}$ ) are the first acid dissociation constants, $R$ is the gas constant $\left(8.314 \mathrm{~m}^{3} \mathrm{~Pa} \mathrm{~K}^{-1} \mathrm{~mol}^{-1}\right), T$ is temperature $(\mathrm{K})$, and $\gamma_{i}$ 's are activity coefficients. We used the web version of AIOMFAC (http://www.aiomfac.caltech.edu, last access: 6 December 2017) (Zuend et al., 2008, 2011, 2012) to compute average $\gamma_{\mathrm{HCOOH}}$ and $\gamma_{\mathrm{CH}_{3} \mathrm{COOH}}$ values of 0.334 and 2.150, respectively. Similar to the case of oxalic acid, we assumed that $\gamma_{\mathrm{H}^{+}} \gamma_{\mathrm{HCOO}^{-}}=\gamma_{\mathrm{H}^{+}} \gamma_{\mathrm{CH}_{3} \mathrm{COO}^{-}}=\gamma_{\mathrm{H}^{+}} \gamma_{\mathrm{NO}_{3}^{-}}$ and used the ISORROPIA-predicted $\gamma_{\mathrm{H}^{+}} \gamma_{\mathrm{NO}_{3}^{-}}$value of 0.07 . Temperature-dependent $\mathrm{H}_{\mathrm{HCOOH}}$ and $\mathrm{H}_{\mathrm{CH}_{3} \mathrm{CO}_{2} \mathrm{H}}$ values are obtained from Sander (2015) using the same methodology employed to determine temperature-dependent $\mathrm{H}_{\mathrm{C}_{2} \mathrm{H}_{2} \mathrm{O}_{4}}$ values. We used $K_{\mathrm{a} 1}$ values at $25^{\circ} \mathrm{C}\left(1.78 \times 10^{-4} \mathrm{moleL}^{-1}\right.$ for formic acid, and $1.75 \times 10^{-5}$ mole $^{-1}$ for acetic acid; Haynes, 2014) for the $\mathrm{S}$ curve calculations.

$\mathrm{S}$ curves for $\varepsilon\left(\mathrm{HCOO}^{-}\right)$and $\varepsilon\left(\mathrm{CH}_{3} \mathrm{CO}_{2}^{-}\right)$calculated based on temperature $=23.4^{\circ} \mathrm{C}$ and $W_{\mathrm{i}}=1.6 \mu \mathrm{g} \mathrm{m}^{-3}$ can be seen in Fig. 8. Practically no formic or acetic acids are predicted to partition to the particle phase (relative to oxalic acid) for the range of $\mathrm{PM}_{1} \mathrm{pH}$ calculated in this study. This is due to significant differences in the Henry's law constants and acid dissociation constants for the three organic acids. $H_{\mathrm{HCOOH}}$ and $\mathrm{H}_{\mathrm{CH}_{3} \mathrm{CO}_{2} \mathrm{H}}$ (9540 and 5370 mole ${ }^{-1} \mathrm{~atm}^{-1}$, respectively) at $23.4^{\circ} \mathrm{C}$ are substantially smaller than $\mathrm{H}_{\mathrm{C}_{2} \mathrm{H}_{2} \mathrm{O}_{4}}$ $\left(7.27 \times 10^{8}\right.$ mole L $\left.^{-1} \mathrm{~atm}^{-1}\right)$ (Sander, 2015). The $K_{\mathrm{a} 1}$ values for formic and acetic acids $\left(1.78 \times 10^{-4}\right.$ and $1.75 \times$ $10^{-5}$ mole $\mathrm{L}^{-1}$, respectively) are also considerably smaller than the $K_{\mathrm{a} 1}$ value for oxalic acid $\left(5.62 \times 10^{-2}\right.$ mole $\left.\mathrm{L}^{-1}\right)$ (Haynes, 2014). Note that $H_{\mathrm{HNO}_{3}}$ is between that of $\mathrm{H}_{\mathrm{C}_{2} \mathrm{H}_{2} \mathrm{O}_{4}}$

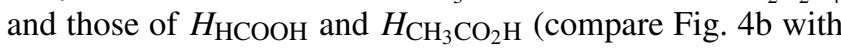
Figs. 7 and 8).

As shown in Fig. 8, higher-than-expected levels of formate and acetate are observed in the particle phase. This has also been reported in previous studies (Liu et al., 2012). Laboratory tests showed that the disagreement cannot be explained by positive biases in the particle-phase formate and acetate PILS-HPIC measurements resulting from less than $100 \%$ gas removal by the carbon denuder. The measured denuder efficiency for formic acid was $\geq 99.97 \%$ (Supplement Sect. S4). The possibility that formic and acetic acid dimers in the aqueous phase (Schrier et al., 1964; Gilson et al., 1997; Chen et al., 2008) may result in higher-than-predicted molar fractions of formate and acetate in the particle phase was explored but also could not explain the observed gas-particle partitioning of these acids (Supplement Sect. S5). The disagreement could be due to incorrect Henry's law constants for formic and acetic acids. However, the Henry's law constants for formic and acetic acid would have to be $\sim 10^{4}$ times and $\sim 3 \times 10^{5}$ times larger than their literature values, respectively, in order for their $\mathrm{S}$ curves to match our measured molar fractions of formic and acetic acid in the particle phase. In addition, formic and acetic acids may not be inter- 

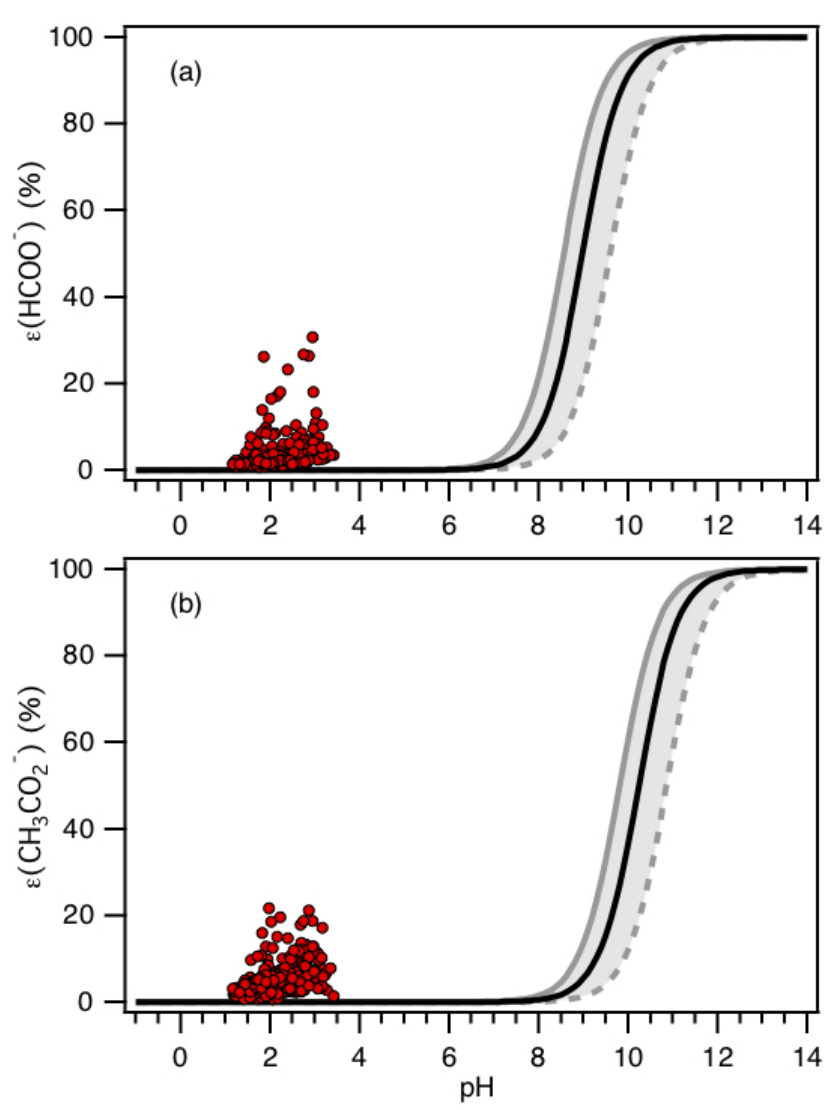

Figure 8. Analytically calculated $\mathrm{S}$ curves of $\varepsilon\left(\mathrm{HCOO}^{-}\right)$and $\varepsilon\left(\mathrm{CH}_{3} \mathrm{CO}_{2}^{-}\right)$(solid black lines) and ambient data from 13 September to 6 October 2016 plotted against ISORROPIA-predicted particle $\mathrm{pH}$ (shown in $\mathbf{a}$ and $\mathbf{b}$, respectively). For the ambient data, a narrow range in $W_{\mathrm{i}}\left(0.5\right.$ to $\left.4 \mu \mathrm{g} \mathrm{m}^{-3}\right)$ and $\mathrm{RH}$ ( $20 \%$ to $90 \%$ ) is chosen to be close to the analytically calculated outputs. For the analytically calculated $\mathrm{S}$ curves, we used $\gamma_{\mathrm{HCOOH}}=0.334$ and $\gamma_{\mathrm{CH}_{3} \mathrm{COOH}}=2.150$ (AIOMFAC predicted). We also assumed that $\gamma_{\mathrm{H}^{+}} \gamma_{\mathrm{HCOO}^{-}}=\gamma_{\mathrm{H}^{+}} \gamma_{\mathrm{CH}_{3} \mathrm{COO}^{-}}=$ $\gamma_{\mathrm{H}^{+}} \gamma_{\mathrm{NO}_{3}^{-}}$and used the ISORROPIA-predicted $\gamma_{\mathrm{H}^{+}-\mathrm{NO}_{3}^{-}}=$ $\sqrt{\gamma_{\mathrm{H}^{+}} \gamma_{\mathrm{NO}_{3}^{-}}}=0.265$. The black lines are $\mathrm{S}$ curves calculated using the selected time period's average temperature $\left(23.4 \pm 4.0^{\circ} \mathrm{C}\right)$ and $W_{\mathrm{i}}\left(1.6 \pm 1.7 \mu \mathrm{g} \mathrm{m}^{-3}\right)$. The grey lines are $\mathrm{S}$ curves calculated using 1 standard deviation from the average temperature and $W_{\mathrm{i}}$ (i.e., temperature $=27.4^{\circ} \mathrm{C}$ and $W_{\mathrm{i}}=0.5 \mu \mathrm{g} \mathrm{m}^{-3}$ for dotted grey line; temperature $=19.4^{\circ} \mathrm{C}$ and $W_{\mathrm{i}}=3.3 \mu \mathrm{g} \mathrm{m}^{-3}$ for solid grey line).

nally mixed with most of the other $\mathrm{PM}_{1}$ aerosol components (e.g., $\mathrm{SO}_{4}^{2-}, \mathrm{NO}_{3}^{-}, \mathrm{NH}_{4}^{+}, \mathrm{C}_{2} \mathrm{O}_{4}^{2-}$ ) and thus are not associated with acidic aerosols, as assumed above. They may instead be associated with aerosols largely composed of non-volatile cations and have a $\mathrm{pH}$ closer to neutral. More research is needed to explain this disagreement.

\section{Summary}

Gas- and particle-phase measurements were conducted in Yorkville, Georgia (a rural field site), during fall 2016. The goal of the field study was to understand how $\mathrm{NH}_{3}$ affects particle acidity and consequently SOA formation through the gas-particle partitioning of semi-volatile inorganic and organic compounds. Since it is a rural site surrounded by forest, agricultural land, and CAFOs, this study provided an opportunity for ambient observations in an area impacted by high local emissions of BVOCs and $\mathrm{NH}_{3}$.

$\mathrm{NH}_{3}$ concentrations measured by the $\mathrm{NH}_{3}$-CIMS ranged from 0.7 to $39.0 \mathrm{ppb}$ (average $8.1 \pm 5.2 \mathrm{ppb}$ ), which were substantially higher than typical levels in the southeastern US. $\mathrm{PM}_{1}$ inorganic chemical composition, gas-phase $\mathrm{HNO}_{3}$ and $\mathrm{NH}_{3}$ concentrations, temperature, and $\mathrm{RH}$ were used as model inputs in the ISORROPIA II thermodynamic model to calculate $\mathrm{PM}_{1} \mathrm{pH}$ and $W_{\mathrm{i}} . \mathrm{PM}_{1} \mathrm{pH}$ ranged from 0.9 to 3.8 , with an average $\mathrm{pH}$ of $2.2 \pm 0.6$. The measured and predicted $\mathrm{HNO}_{3}-\mathrm{NO}_{3}^{-}$and $\mathrm{NH}_{3}-\mathrm{NH}_{4}^{+}$gas-particle partitioning ratios were in good agreement. The measured gasphase organic acids were estimated to contribute $30 \%$ of the overall $\mathrm{WSOC}_{\mathrm{g}}$ on a carbon mass basis, whereas measured particle-phase organic acids comprised $6 \%$ of the total organic aerosol mass concentration and $4 \%$ of the overall $\mathrm{WSOC}_{\mathrm{p}}$ on a carbon mass basis. Formic and acetic acids were the most abundant gas-phase organic acids, with averages of $2.2 \pm 1.6$ and $1.9 \pm 1.3 \mu \mathrm{g} \mathrm{m}^{-3}$, respectively. Oxalate was the most abundant particle-phase water-soluble organic acid anion, with an average of $0.07 \pm 0.05 \mu \mathrm{g} \mathrm{m}^{-3}$. Measured oxalic acid gas-particle partitioning ratios generally agreed with analytical predictions, which were based on oxalic acid's physicochemical properties (specifically, its Henry's law constants, acid dissociation constants, and activity coefficients), temperature, $W_{\mathrm{i}}$, and particle $\mathrm{pH}$. The partitioning of oxalic acid to the particle phase is highly sensitive to temperature and $W_{\mathrm{i}}$. In contrast, the partitioning of formic and acetic acids to the particle phase was higher than predicted for reasons currently unknown.

Although past air regulations have resulted in decreased sulfate, nitrate, and ammonium aerosol mass concentrations across the US, our study suggests that the current limited regulation of $\mathrm{NH}_{3}$ emissions may result in some increase in the organic aerosol mass concentration due to increased gas-toparticle partitioning of some organic acids. However, in this study, the effect was small since the organic acids comprised a small fraction of the overall organic aerosol mass.

Data availability. Data can be accessed by request (rweber@eas.gatech.edu).

Supplement. The supplement related to this article is available online at: https://doi.org/10.5194/acp-18-11471-2018-supplement. 
Author contributions. Principle investigator RJW and coinvestigators LGH, NLN, and AR planned the field study. TN, HG, APS, YC, and DJT conducted the field study. TN, HG, APS, and YC analyzed the data. TN, RJW, LGH, NLN, AR, and AN were involved in data interpretation. TN and RJW wrote the paper.

Competing interests. The authors declare that they have no conflict of interest.

Acknowledgements. The authors thank Eric Edgerton (Atmospheric Research and Analysis, Inc.) for providing SEARCH network measurements and meteorological data.

This publication was developed under U.S. Environmental Protection Agency (EPA) STAR grant R835882 awarded to the Georgia Institute of Technology. It has not been formally reviewed by the EPA. The views expressed in this document are solely those of the authors and do not necessarily reflect those of the EPA. The EPA does not endorse any products or commercial services mentioned in this publication.

Edited by: Kimitaka Kawamura

Reviewed by: two anonymous referees

\section{References}

Barbier Jr., J. and Duprez, D.: Steam Effects in 3way catalysis, Appl. Catal. B-Environ., 4, 105-140, https://doi.org/10.1016/0926-3373(94)80046-4, 1994.

Bertram, A. K., Martin, S. T., Hanna, S. J., Smith, M. L., Bodsworth, A., Chen, Q., Kuwata, M., Liu, A., You, Y., and Zorn, S. R.: Predicting the relative humidities of liquid-liquid phase separation, efflorescence, and deliquescence of mixed particles of ammonium sulfate, organic material, and water using the organic-to-sulfate mass ratio of the particle and the oxygen-tocarbon elemental ratio of the organic component, Atmos. Chem. Phys., 11, 10995-11006, https://doi.org/10.5194/acp-11-109952011, 2011.

Blanchard, C. L., Hidy, G. M., Tanenbaum, S., and Edgerton, E. S.: NMOC, ozone, and organic aerosol in the southeastern United States, 1999-2007: 3. Origins of organic aerosol in Atlanta, Georgia, and surrounding areas, Atmos. Environ., 45, 12911302, https://doi.org/10.1016/j.atmosenv.2010.12.004, 2011.

Blanchard, C. L., Hidy, G. M., Tanenbaum, S., Edgerton, E. S., and Hartsell, B. E.: The Southeastern Aerosol Research and Characterization (SEARCH) study: Spatial variations and chemical climatology, 1999-2010, J. Air Waste Manage., 63, 260-275, https://doi.org/10.1080/10962247.2012.749816, 2013a.

Blanchard, C. L., Hidy, G. M., Tanenbaum, S., Edgerton, E. S., and Hartsell, B. E.: The Southeastern Aerosol Research and Characterization (SEARCH) study: Temporal trends in gas and PM concentrations and composition, 1999-2010, J. Air Waste Manage., 63, 247-259, https://doi.org/10.1080/10962247.2012.748523, $2013 b$.

Blanchard, C. L., Tanenbaum, S., and Hidy, G. M.: Source Attribution of Air Pollutant Concentrations and Trends in the Southeastern Aerosol Research and Characterization
(SEARCH) Network, Environ. Sci. Technol., 47, 13536-13545, https://doi.org/10.1021/es402876s, 2013c.

Bougiatioti, A., Nikolaou, P., Stavroulas, I., Kouvarakis, G., Weber, R., Nenes, A., Kanakidou, M., and Mihalopoulos, N.: Particle water and $\mathrm{pH}$ in the eastern Mediterranean: source variability and implications for nutrient availability, Atmos. Chem. Phys., 16, 4579-4591, https://doi.org/10.5194/acp-16-4579-2016, 2016.

Boyd, C. M., Sanchez, J., Xu, L., Eugene, A. J., Nah, T., Tuet, W. Y., Guzman, M. I., and Ng, N. L.: Secondary organic aerosol formation from the $\beta$-pinene $+\mathrm{NO}_{3}$ system: effect of humidity and peroxy radical fate, Atmos. Chem. Phys., 15, 7497-7522, https://doi.org/10.5194/acp-15-7497-2015, 2015.

Boyd, C. M., Nah, T., Xu, L., Berkemeier, T., and $\mathrm{Ng}$, N. L.: Secondary Organic Aerosol (SOA) from Nitrate Radical Oxidation of Monoterpenes: Effects of Temperature, Dilution, and Humidity on Aerosol Formation, Mixing, and Evaporation, Environ. Sci. Technol., 51, 7831-7841, https://doi.org/10.1021/acs.est.7b01460, 2017.

Canagaratna, M. R., Jayne, J. T., Jimenez, J. L., Allan, J. D., Alfarra, M. R., Zhang, Q., Onasch, T. B., Drewnick, F., Coe, H., Middlebrook, A., Delia, A., Williams, L. R., Trimborn, A. M., Northway, M. J., DeCarlo, P. F., Kolb, C. E., Davidovits, P., and Worsnop, D. R.: Chemical and microphysical characterization of ambient aerosols with the aerodyne aerosol mass spectrometer, Mass Spectrom. Rev., 26, 185-222, https://doi.org/10.1002/mas.20115, 2007.

Canagaratna, M. R., Jimenez, J. L., Kroll, J. H., Chen, Q., Kessler, S. H., Massoli, P., Hildebrandt Ruiz, L., Fortner, E., Williams, L. R., Wilson, K. R., Surratt, J. D., Donahue, N. M., Jayne, J. T., and Worsnop, D. R.: Elemental ratio measurements of organic compounds using aerosol mass spectrometry: characterization, improved calibration, and implications, Atmos. Chem. Phys., 15, 253-272, https://doi.org/10.5194/acp-15-253-2015, 2015.

Case, J. L. and Zavodsky, B. T.: Evolution of 2016 drought in the Southeastern United States from a Land surface modeling perspective, Results Phys., 8, 654-656, https://doi.org/10.1016/j.rinp.2017.12.029, 2018.

Chen, J. H., Brooks, C. L., and Scheraga, H. A.: Revisiting the carboxylic acid dimers in aqueous solution: Interplay of hydrogen bonding, hydrophobic interactions, and entropy, J. Phys. Chem. B, 112, 242-249, https://doi.org/10.1021/jp074355h, 2008.

Clegg, S. L. and Brimblecombe, P.: Equilibrium partial pressures and mean activity and osmotic coefficients of 0-100-percent nitric-acid as a function of temperature, J. Phys. Chem., 94, 5369-5380, https://doi.org/10.1021/j100376a038, 1990.

Clegg, S. L., Brimblecombe, P., and Khan, L.: The Henry's law constant of oxalic acid and its partitioning into the atmospheric aerosol, Idojaras, 100, 51-68, 1996.

Clegg, S. L., Brimblecombe, P., and Wexler, A. S.: Thermodynamic model of the system $\mathrm{H}^{+}-\mathrm{NH}_{4}^{+}-\mathrm{SO}_{4}^{2-}-\mathrm{NO}_{3}^{-}-\mathrm{H}_{2} \mathrm{O}$ at tropospheric temperatures, J. Phys. Chem. A, 102, 2137-2154, https://doi.org/10.1021/jp973042r, 1998.

Compernolle, S. and Müller, J.-F.: Henry's law constants of diacids and hydroxy polyacids: recommended values, Atmos. Chem. Phys., 14, 2699-2712, https://doi.org/10.5194/acp-142699-2014, 2014.

DeCarlo, P. F., Kimmel, J. R., Trimborn, A., Northway, M. J., Jayne, J. T., Aiken, A. C., Gonin, M., Fuhrer, K., Horvath, T., Docherty, K. S., Worsnop, D. R., and 
Jimenez, J. L.: Field-deployable, high-resolution, time-of-flight aerosol mass spectrometer, Anal. Chem., 78, 8281-8289, https://doi.org/10.1021/ac061249n, 2006.

Dentener, F. J. and Crutzen, P. J.: A three-dimensional model of the global ammonia cycle, J. Atmos. Chem., 19, 331-369, https://doi.org/10.1007/bf00694492, 1994.

Eatough, D. J., Wadsworth, A., Eatough, D. A., Crawford, J. W., Hansen, L. D., and Lewis, E. A.: A multiple-system, multi-channel diffusion denuder sampler for the determination of fine-particulate organic material in the atmosphere, Atmos. Environ. A-Gen., 27, 1213-1219, https://doi.org/10.1016/09601686(93)90247-V, 1993.

Edgerton, E. S., Hartsell, B. E., Saylor, R. D., Jansen, J. J., Hansen, D. A., and Hidy, G. M.: The southeastern aerosol research and characterization study: Part II. Filter-based measurements of fine and coarse particulate matter mass and composition, J. Air Waste Manage., 55, 1527-1542, 2005.

Edgerton, E. S., Hartsell, B. E., Saylor, R. D., Jansen, J. J., Hansen, D. A., and Hidy, G. M.: The Southeastern Aerosol Research and Characterization Study, part 3: Continuous measurements of fine particulate matter mass and composition, J. Air Waste Manage., 56, 1325-1341, https://doi.org/10.1080/10473289.2006.10464585, 2006.

Edgerton, E. S., Saylor, R. D., Hartsell, B. E., Jansen, J. J., and Hansen, D. A.: Ammonia and ammonium measurements from the southeastern United States, Atmos. Environ., 41, 3339-3351, https://doi.org/10.1016/j.atmosenv.2006.12.034, 2007.

Ellis, R. A., Murphy, J. G., Markovic, M. Z., VandenBoer, T. C., Makar, P. A., Brook, J., and Mihele, C.: The influence of gasparticle partitioning and surface-atmosphere exchange on ammonia during BAQS-Met, Atmos. Chem. Phys., 11, 133-145, https://doi.org/10.5194/acp-11-133-2011, 2011.

Ellis, R. A., Jacob, D. J., Sulprizio, M. P., Zhang, L., Holmes, C. D., Schichtel, B. A., Blett, T., Porter, E., Pardo, L. H., and Lynch, J. A.: Present and future nitrogen deposition to national parks in the United States: critical load exceedances, Atmos. Chem. Phys., 13, 9083-9095, https://doi.org/10.5194/acp13-9083-2013, 2013.

Ervens, B., Feingold, G., Frost, G. J., and Kreidenweis, S. M.: A modeling study of aqueous production of dicarboxylic acids: 1. Chemical pathways and speciated organic mass production, J. Geophys. Res.-Atmos., 109, D15205, https://doi.org/10.1029/2003jd004387, 2004.

Fountoukis, C. and Nenes, A.: ISORROPIA II: a computationally efficient thermodynamic equilibrium model for $\mathrm{K}^{+}-$ $\mathrm{Ca}^{2+}-\mathrm{Mg}^{2+}-\mathrm{NH}_{4}^{+}-\mathrm{Na}^{+}-\mathrm{SO}_{4}^{2-}-\mathrm{NO}_{3}^{-}-\mathrm{Cl}^{-}-\mathrm{H}_{2} \mathrm{O}$ aerosols, Atmos. Chem. Phys., 7, 4639-4659, https://doi.org/10.5194/acp-74639-2007, 2007.

Gilson, M. K., Given, J. A., Bush, B. L., and McCammon, J. A.: The statistical-thermodynamic basis for computation of binding affinities: A critical review, Biophys. J., 72, 1047-1069, https://doi.org/10.1016/s0006-3495(97)78756-3, 1997.

Guenther, A. B., Jiang, X., Heald, C. L., Sakulyanontvittaya, T., Duhl, T., Emmons, L. K., and Wang, X.: The Model of Emissions of Gases and Aerosols from Nature version 2.1 (MEGAN2.1): an extended and updated framework for modeling biogenic emissions, Geosci. Model Dev., 5, 1471-1492, https://doi.org/10.5194/gmd-5-1471-2012, 2012.
Guo, H., Xu, L., Bougiatioti, A., Cerully, K. M., Capps, S. L., Hite Jr., J. R., Carlton, A. G., Lee, S.-H., Bergin, M. H., Ng, N. L., Nenes, A., and Weber, R. J.: Fine-particle water and $\mathrm{pH}$ in the southeastern United States, Atmos. Chem. Phys., 15, 5211-5228, https://doi.org/10.5194/acp-15-5211-2015, 2015.

Guo, H., Sullivan, A. P., Campuzano-Jost, P., Schroder, J. C., LopezHilfiker, F. D., Dibb, J. E., Jimenez, J. L., Thornton, J. A., Brown, S. S., Nenes, A., and Weber, R. J.: Fine particle pH and the partitioning of nitric acid during winter in the northeastern United States, J. Geophys. Res.-Atmos., 121, 10355-10376, https://doi.org/10.1002/2016jd025311, 2016.

Guo, H., Liu, J., Froyd, K. D., Roberts, J. M., Veres, P. R., Hayes, P. L., Jimenez, J. L., Nenes, A., and Weber, R. J.: Fine particle $\mathrm{pH}$ and gas-particle phase partitioning of inorganic species in Pasadena, California, during the 2010 CalNex campaign, Atmos. Chem. Phys., 17, 5703-5719, https://doi.org/10.5194/acp17-5703-2017, 2017a.

Guo, H., Nenes, A., and Weber, R. J.: The underappreciated role of nonvolatile cations on aerosol ammonium-sulfate molar ratios, Atmos. Chem. Phys. Discuss., https://doi.org/10.5194/acp-2017737, in review, 2017b.

Guo, H., Weber, R. J., and Nenes, A.: High levels of ammonia do not raise fine particle $\mathrm{pH}$ sufficiently to yield nitrogen oxide-dominated sulfate production, Sci. Rep.-UK, 7, 12109, https://doi.org/10.1038/s41598-017-11704-0, 2017c.

Hansen, D. A., Edgerton, E. S., Hartsell, B. E., Jansen, J. J., Kandasamy, N., Hidy, G. M., and Blanchard, C. L.: The southeastern aerosol research and characterization study: Part 1 - overview, J. Air Waste Manage., 53, 1460-1471, 2003.

Haynes, W. M.: CRC handbook of chemistry and physics: A readyreference book of chemical and physical data, CRC Press, Boca Raton, 2014.

Hennigan, C. J., Izumi, J., Sullivan, A. P., Weber, R. J., and Nenes, A.: A critical evaluation of proxy methods used to estimate the acidity of atmospheric particles, Atmos. Chem. Phys., 15, 27752790, https://doi.org/10.5194/acp-15-2775-2015, 2015.

Huey, L. G., Hanson, D. R., and Howard, C. J.: Reactions of $\mathrm{SF}_{6}^{-}$ and $\mathrm{I}^{-}$with Atmospheric Trace Gases, J. Phys. Chem., 99, 50015008, https://doi.org/10.1021/j100014a021, 1995.

Huey, L. G., Tanner, D. J., Slusher, D. L., Dibb, J. E., Arimoto, R., Chen, G., Davis, D., Buhr, M. P., Nowak, J. B., Mauldin, R. L., Eisele, F. L., and Kosciuch, E.: CIMS measurements of HNO3 and SO 2 at the South Pole during ISCAT 2000, Atmos. Environ., 38, 5411-5421, https://doi.org/10.1016/j.atmosenv.2004.04.037, 2004.

Kawamura, K. and Bikkina, S.: A review of dicarboxylic acids and related compounds in atmospheric aerosols: Molecular distributions, sources and transformation, Atmos. Res., 170, 140-160, https://doi.org/10.1016/j.atmosres.2015.11.018, 2016.

Kawamura, K. and Gagosian, R. B.: Implication of omegaoxocarboxylic acids in the remote marine atmosphere for photooxidation of unsaturated fatty acids, Nature, 325, 330-332, https://doi.org/10.1038/325330a0, 1987.

Kawamura, K. and Ikushima, K.: Seasonal changes in the distribution of dicarboxylic acids in the urban atmosphere, Environ. Sci. Technol., 27, 2227-2235, https://doi.org/10.1021/es00047a033, 1993.

Kerminen, V. M., Ojanen, C., Pakkanen, T., Hillamo, R., Aurela, M., and Merilainen, J.: Low-molecular-weight dicarboxylic acids 
in an urban and rural atmosphere, J. Aerosol Sci., 31, 349-362, https://doi.org/10.1016/s0021-8502(99)00063-4, 2000.

Lamarque, J.-F., Bond, T. C., Eyring, V., Granier, C., Heil, A., Klimont, Z., Lee, D., Liousse, C., Mieville, A., Owen, B., Schultz, M. G., Shindell, D., Smith, S. J., Stehfest, E., Van Aardenne, J., Cooper, O. R., Kainuma, M., Mahowald, N., McConnell, J. R., Naik, V., Riahi, K., and van Vuuren, D. P.: Historical (1850-2000) gridded anthropogenic and biomass burning emissions of reactive gases and aerosols: methodology and application, Atmos. Chem. Phys., 10, 7017-7039, https://doi.org/10.5194/acp-10-7017-2010, 2010.

Laskin, A., Laskin, J., and Nizkorodov, S. A.: Chemistry of Atmospheric Brown Carbon, Chem. Rev., 115, 4335-4382, https://doi.org/10.1021/cr5006167, 2015.

Laskin, J., Laskin, A., Roach, P. J., Slysz, G. W., Anderson, G. A., Nizkorodov, S. A., Bones, D. L., and Nguyen, L. Q.: High-Resolution Desorption Electrospray Ionization Mass Spectrometry for Chemical Characterization of Organic Aerosols, Anal. Chem., 82, 2048-2058, https://doi.org/10.1021/ac902801f, 2010.

Lee, B. H., Mohr, C., Lopez-Hilfiker, F. D., Lutz, A., Hallquist, M., Lee, L., Romer, P., Cohen, R. C., Iyer, S., Kurten, T., Hu, W. W., Day, D. A., Campuzano-Jost, P., Jimenez, J. L., Xu, L., Ng, N. L., Guo, H. Y., Weber, R. J., Wild, R. J., Brown, S. S., Koss, A., de Gouw, J., Olson, K., Goldstein, A. H., Seco, R., Kim, S., McAvey, K., Shepson, P. B., Starn, T., Baumann, K., Edgerton, E. S., Liu, J. M., Shilling, J. E., Miller, D. O., Brune, W., Schobesberger, S., D'Ambro, E. L., and Thornton, J. A.: Highly functionalized organic nitrates in the southeast United States: Contribution to secondary organic aerosol and reactive nitrogen budgets, P. Natl. Acad. Sci. USA, 113, 1516-1521, https://doi.org/10.1073/pnas.1508108113, 2016.

Lee, B. P., Li, Y. J., Yu, J. Z., Louie, P. K. K., and Chan, C. K.: Characteristics of submicron particulate matter at the urban roadside in downtown Hong Kong-Overview of 4 months of continuous high-resolution aerosol mass spectrometer measurements, J. Geophys. Res.-Atmos., 120, 7040-7058, https://doi.org/10.1002/2015jd023311, 2015.

Lee, H. J., Laskin, A., Laskin, J., and Nizkorodov, S. A.: ExcitationEmission Spectra and Fluorescence Quantum Yields for Fresh and Aged Biogenic Secondary Organic Aerosols, Environ. Sci. Technol., 47, 5763-5770, https://doi.org/10.1021/es400644c, 2013.

Lim, H. J., Carlton, A. G., and Turpin, B. J.: Isoprene forms secondary organic aerosol through cloud processing: Model simulations, Environ. Sci. Technol., 39, 4441-4446, https://doi.org/10.1021/es048039h, 2005.

Liu, J., Zhang, X., Parker, E. T., Veres, P. R., Roberts, J. M., de Gouw, J. A., Hayes, P. L., Jimenez, J. L., Murphy, J. G., Ellis, R. A., Huey, L. G., and Weber, R. J.: On the gasparticle partitioning of soluble organic aerosol in two urban atmospheres with contrasting emissions: 2. Gas and particle phase formic acid, J. Geophys. Res.-Atmos., 117, D00V21, https://doi.org/10.1029/2012jd017912, 2012.

Livingston, C., Rieger, P., and Winer, A.: Ammonia emissions from a representative in-use fleet of light and medium-duty vehicles in the California South Coast Air Basin, Atmos. Environ., 43, 3326-3333, https://doi.org/10.1016/j.atmosenv.2009.04.009, 2009.
Malm, W. C. and Day, D. E.: Estimates of aerosol species scattering characteristics as a function of relative humidity, Atmos. Environ., 35, 2845-2860, https://doi.org/10.1016/s13522310(01)00077-2, 2001.

Middlebrook, A. M., Bahreini, R., Jimenez, J. L., and Canagaratna, M. R.: Evaluation of Composition-Dependent Collection Efficiencies for the Aerodyne Aerosol Mass Spectrometer using Field Data, Aerosol Sci. Tech., 46, 258-271, https://doi.org/10.1080/02786826.2011.620041, 2012.

Na, K., Song, C., Switzer, C., and Cocker, D. R.: Effect of ammonia on secondary organic aerosol formation from alpha-Pinene ozonolysis in dry and humid conditions, Environ. Sci. Technol., 41, 6096-6102, https://doi.org/10.1021/es061956y, 2007.

Nah, T., Ji, Y., Tanner, D. J., Guo, H., Sullivan, A. P., Ng, N. L., Weber, R. J., and Huey, L. G.: Real-time measurements of gas-phase organic acids using $\mathrm{SF}_{6}^{-}$chemical ionization mass spectrometry, Atmos. Meas. Tech. Discuss., https://doi.org/10.5194/amt-201846, in review, 2018.

Nenes, A., Pandis, S. N., and Pilinis, C.: ISORROPIA: A new thermodynamic equilibrium model for multiphase multicomponent inorganic aerosols, Aquat. Geochem., 4, 123-152, https://doi.org/10.1023/a:1009604003981, 1998.

Neuman, J. A., Ryerson, T. B., Huey, L. G., Jakoubek, R., Nowak, J. B., Simons, C., and Fehsenfeld, F. C.: Calibration and evaluation of nitric acid and ammonia permeation tubes by UV optical absorption, Environ. Sci. Technol., 37, 2975-2981, https://doi.org/10.1021/es026422I, 2003.

Ng, N. L., Brown, S. S., Archibald, A. T., Atlas, E., Cohen, R. C., Crowley, J. N., Day, D. A., Donahue, N. M., Fry, J. L., Fuchs, H., Griffin, R. J., Guzman, M. I., Herrmann, H., Hodzic, A., Iinuma, Y., Jimenez, J. L., Kiendler-Scharr, A., Lee, B. H., Luecken, D. J., Mao, J., McLaren, R., Mutzel, A., Osthoff, H. D., Ouyang, B., Picquet-Varrault, B., Platt, U., Pye, H. O. T., Rudich, Y., Schwantes, R. H., Shiraiwa, M., Stutz, J., Thornton, J. A., Tilgner, A., Williams, B. J., and Zaveri, R. A.: Nitrate radicals and biogenic volatile organic compounds: oxidation, mechanisms, and organic aerosol, Atmos. Chem. Phys., 17, 2103-2162, https://doi.org/10.5194/acp-17-2103-2017, 2017.

Nowak, J. B., Huey, L. G., Eisele, F. L., Tanner, D. J., Mauldin, R. L., Cantrell, C., Kosciuch, E., and Davis, D. D.: Chemical ionization mass spectrometry technique for detection of dimethylsulfoxide and ammonia, J. Geophys. Res.-Atmos., 107, 4363, https://doi.org/10.1029/2001jd001058, 2002.

Nowak, J. B., Huey, L. G., Russell, A. G., Tian, D., Neuman, J. A., Orsini, D., Sjostedt, S. J., Sullivan, A. P., Tanner, D. J., Weber, R. J., Nenes, A., Edgerton, E., and Fehsenfeld, F. C.: Analysis of urban gas phase ammonia measurements from the 2002 Atlanta Aerosol Nucleation and Real-Time Characterization Experiment (ANARChE), J. Geophys. Res.-Atmos., 111, 14, https://doi.org/10.1029/2006jd007113, 2006.

Orsini, D. A., Ma, Y. L., Sullivan, A., Sierau, B., Baumann, K., and Weber, R. J.: Refinements to the particle-into-liquid sampler (PILS) for ground and airborne measurements of water soluble aerosol composition, Atmos. Environ., 37, 1243-1259, https://doi.org/10.1016/s1352-2310(02)01015-4, 2003.

Park Williams, A., Cook, B. I., Smerdon, J. E., Bishop, D. A., Seager, R., and Mankin, J. S.: The 2016 Southeastern U.S. Drought: An Extreme Departure From Centennial Wet- 
ting and Cooling, J. Geophys. Res.-Atmos., 122, 10888-10905, https://doi.org/10.1002/2017JD027523, 2017.

Pechony, O. and Shindell, D. T.: Driving forces of global wildfires over the past millennium and the forthcoming century, P. Natl. Acad. Sci. USA, 107, 19167-19170, https://doi.org/10.1073/pnas.1003669107, 2010.

Pye, H. O. T., Luecken, D. J., Xu, L., Boyd, C. M., Ng, N. L., Baker, K. R., Ayres, B. R., Bash, J. O., Baumann, K., Carter, W. P. L., Edgerton, E., Fry, J. L., Hutzell, W. T., Schwede, D. B., and Shepson, P. B.: Modeling the Current and Future Roles of Particulate Organic Nitrates in the Southeastern United States, Environ. Sci. Technol., 49, 14195-14203, https://doi.org/10.1021/acs.est.5b03738, 2015.

Reis, S., Pinder, R. W., Zhang, M., Lijie, G., and Sutton, M. A.: Reactive nitrogen in atmospheric emission inventories, Atmos. Chem. Phys., 9, 7657-7677, https://doi.org/10.5194/acp-9-76572009, 2009.

Sander, R.: Compilation of Henry's law constants (version 4.0) for water as solvent, Atmos. Chem. Phys., 15, 4399-4981, https://doi.org/10.5194/acp-15-4399-2015, 2015.

Saxena, P. and Hildemann, L. M.: Water-soluble organics in atmospheric particles: A critical review of the literature and application of thermodynamics to identify candidate compounds, J. Atmos. Chem., 24, 57-109, https://doi.org/10.1007/bf00053823, 1996.

Saylor, R., Myles, L., Sibble, D., Caldwell, J., and Xing, J.: Recent trends in gas-phase ammonia and $\mathrm{PM}_{2.5}$ ammonium in the Southeast United States, J. Air Waste Manage., 65, 347-357, https://doi.org/10.1080/10962247.2014.992554, 2015.

Schrier, E. E., Pottle, M., and Scheraga, H. A.: The Influence of Hydrogen and Hydrophobic Bonds on the Stability of the Carboxylic Acid Dimers in Aqueous Solution, J. Am. Chem. Soc., 86, 3444-3449, https://doi.org/10.1021/ja01071a009, 1964.

Seinfeld, J. H. and Pandis, S. N.: Atmospheric chemistry and physics: from air pollution to climate change, Third edn., John Wiley \& Sons, Inc., Hoboken, New Jersey, xxvi, 1120 pp., 2016.

Shi, G. L., Xu, J., Peng, X., Xiao, Z. M., Chen, K., Tian, Y. Z., Guan, X. B., Feng, Y. C., Yu, H. F., Nenes, A., and Russell, A. G.: pH of Aerosols in a Polluted Atmosphere: Source Contributions to Highly Acidic Aerosol, Environ. Sci. Technol., 51, 4289-4296, https://doi.org/10.1021/acs.est.6b05736, 2017.

Song, M., Marcolli, C., Krieger, U. K., Zuend, A., and Peter, T.: Liquid-liquid phase separation and morphology of internally mixed dicarboxylic acids/ammonium sulfate/water particles, Atmos. Chem. Phys., 12, 2691-2712, https://doi.org/10.5194/acp12-2691-2012, 2012.

Song, S., Gao, M., Xu, W., Shao, J., Shi, G., Wang, S., Wang, Y., Sun, Y., and McElroy, M. B.: Fine-particle pH for Beijing winter haze as inferred from different thermodynamic equilibrium models, Atmos. Chem. Phys., 18, 7423-7438, https://doi.org/10.5194/acp-18-7423-2018, 2018.

Sorooshian, A., Ng, N. L., Chan, A. W. H., Feingold, G., Flagan, R. C., and Seinfeld, J. H.: Particulate organic acids and overall water-soluble aerosol composition measurements from the 2006 Gulf of Mexico Atmospheric Composition and Climate Study (GoMACCS), J. Geophys. Res.-Atmos., 112, 16, https://doi.org/10.1029/2007jd008537, 2007.

Sorooshian, A., Murphy, S. M., Hersey, S., Bahreini, R., Jonsson, H., Flagan, R. C., and Seinfeld, J. H.: Constraining the contribution of organic acids and AMS $m / z, 44$ to the organic aerosol budget: On the importance of meteorology, aerosol hygroscopicity, and region, Geophys. Res. Lett., 37, 5, https://doi.org/10.1029/2010g1044951, 2010.

Spaulding, R. S., Talbot, R. W., and Charles, M. J.: Optimization of a mist chamber (cofer scrubber) for sampling watersoluble organics in air, Environ. Sci. Technol., 36, 1798-1808, https://doi.org/10.1021/es011189x, 2002.

Suarez-Bertoa, R., Zardini, A. A., and Astorga, C.: Ammonia exhaust emissions from spark ignition vehicles over the New European Driving Cycle, Atmos. Environ., 97, 43-53, https://doi.org/10.1016/j.atmosenv.2014.07.050, 2014.

Sullivan, A. P., Weber, R. J., Clements, A. L., Turner, J. R., Bae, M. S., and Schauer, J. J.: A method for on-line measurement of water-soluble organic carbon in ambient aerosol particles: Results from an urban site, Geophys. Res. Lett., 31, L13105, https://doi.org/10.1029/2004gl019681, 2004.

Sun, K., Tao, L., Miller, D. J., Pan, D., Golston, L. M., Zondlo, M. A., Griffin, R. J., Wallace, H. W., Leong, Y. J., Yang, M. M., Zhang, Y., Mauzerall, D. L., and Zhu, T.: Vehicle Emissions as an Important Urban Ammonia Source in the United States and China, Environ. Sci. Technol., 51, 2472-2481, https://doi.org/10.1021/acs.est.6b02805, 2017.

Updyke, K. M., Nguyen, T. B., and Nizkorodov, S. A.: Formation of brown carbon via reactions of ammonia with secondary organic aerosols from biogenic and anthropogenic precursors, Atmos. Environ., 63, 22-31, https://doi.org/10.1016/j.atmosenv.2012.09.012, 2012.

Van Damme, M., Clarisse, L., Heald, C. L., Hurtmans, D., Ngadi, Y., Clerbaux, C., Dolman, A. J., Erisman, J. W., and Coheur, P. F.: Global distributions, time series and error characterization of atmospheric ammonia $\left(\mathrm{NH}_{3}\right)$ from IASI satellite observations, Atmos. Chem. Phys., 14, 2905-2922, https://doi.org/10.5194/acp14-2905-2014, 2014.

Warner, J. X., Wei, Z., Strow, L. L., Dickerson, R. R., and Nowak, J. B.: The global tropospheric ammonia distribution as seen in the 13-year AIRS measurement record, Atmos. Chem. Phys., 16, 5467-5479, https://doi.org/10.5194/acp-16-5467-2016, 2016.

Warner, J. X., Dickerson, R. R., Wei, Z., Strow, L. L., Wang, Y., and Liang, Q.: Increased atmospheric ammonia over the world's major agricultural areas detected from space, Geophys. Res. Lett., 44, 2875-2884, https://doi.org/10.1002/2016g1072305, 2017.

Weber, R. J., Orsini, D., Daun, Y., Lee, Y. N., Klotz, P. J., and Brechtel, F.: A particle-into-liquid collector for rapid measurement of aerosol bulk chemical composition, Aerosol Sci. Tech., 35, 718727, https://doi.org/10.1080/02786820152546761, 2001.

Weber, R. J., Lee, S., Chen, G., Wang, B., Kapustin, V., Moore, K., Clarke, A. D., Mauldin, L., Kosciuch, E., Cantrell, C., Eisele, F., Thornton, D. C., Bandy, A. R., Sachse, G. W., and Fuelberg, H. E.: New particle formation in anthropogenic plumes advecting from Asia observed during TRACE-P, J. Geophys. Res.-Atmos., 108, 13, https://doi.org/10.1029/2002jd003112, 2003.

Weber, R. J., Guo, H., Russell, A. G., and Nenes, A.: High aerosol acidity despite declining atmospheric sulfate concentrations over the past 15 years, Nat. Geosci., 9, 282, https://doi.org/10.1038/ngeo2665, 2016.

Whittington, B. I., Jiang, C. J., and Trimm, D. L.: Vehicle exhaust catalysis: I. The relative importance of catalytic oxidation, steam 
reforming and water-gas shift reactions, Catal. Today, 26, 41-45, https://doi.org/10.1016/0920-5861(95)00093-u, 1995.

Xing, J., Pleim, J., Mathur, R., Pouliot, G., Hogrefe, C., Gan, C.-M., and Wei, C.: Historical gaseous and primary aerosol emissions in the United States from 1990 to 2010, Atmos. Chem. Phys., 13, 7531-7549, https://doi.org/10.5194/acp-13-7531-2013, 2013.

Xu, L., Guo, H., Boyd, C. M., Klein, M., Bougiatioti, A., Cerully, K. M., Hite, J. R., Isaacman-VanWertz, G., Kreisberg, N. M., Knote, C., Olson, K., Koss, A., Goldstein, A. H., Hering, S. V., de Gouw, J., Baumann, K., Lee, S.-H., Nenes, A., Weber, R. J., and $\mathrm{Ng}$, N. L.: Effects of anthropogenic emissions on aerosol formation from isoprene and monoterpenes in the southeastern United States, P. Natl. Acad. Sci. USA, 112, 37-42, https://doi.org/10.1073/pnas.1417609112, 2015a.

$\mathrm{Xu}$, L., Suresh, S., Guo, H., Weber, R. J., and Ng, N. L.: Aerosol characterization over the southeastern United States using high-resolution aerosol mass spectrometry: spatial and seasonal variation of aerosol composition and sources with a focus on organic nitrates, Atmos. Chem. Phys., 15, 7307-7336, https://doi.org/10.5194/acp-15-7307-2015, 2015b.

Xu, L., Middlebrook, A. M., Liao, J., de Gouw, J. A., Guo, H., Weber, R. J., Nenes, A., Lopez-Hilfiker, F. D., Lee, B. H., Thornton, J. A., Brock, C. A., Neuman, J. A., Nowak, J. B., Pollack, I. B., Welti, A., Graus, M., Warneke, C., and $\mathrm{Ng}, \mathrm{N}$. L.: Enhanced formation of isoprene-derived organic aerosol in sulfur-rich power plant plumes during Southeast Nexus, J. Geophys. Res.-Atmos., 121, 11137-11153, https://doi.org/10.1002/2016jd025156, 2016.

$\mathrm{Xu}$, L., Guo, H. Y., Weber, R. J., and Ng, N. L.: Chemical Characterization of Water-Soluble Organic Aerosol in Contrasting Rural and Urban Environments in the Southeastern United States, Environ. Sci. Technol., 51, 78-88, https://doi.org/10.1021/acs.est.6b05002, 2017.

Yao, X. H., Hu, Q. J., Zhang, L. M., Evans, G. J., Godri, K. J., and $\mathrm{Ng}, \mathrm{A}$. C.: Is vehicular emission a significant contributor to ammonia in the urban atmosphere?, Atmos. Environ., 80, 499506, https://doi.org/10.1016/j.atmosenv.2013.08.028, 2013.

You, Y. and Bertram, A. K.: Effects of molecular weight and temperature on liquid-liquid phase separation in particles containing organic species and inorganic salts, Atmos. Chem. Phys., 15, 1351-1365, https://doi.org/10.5194/acp-15-1351-2015, 2015.

You, Y., Renbaum-Wolff, L., and Bertram, A. K.: Liquid-liquid phase separation in particles containing organics mixed with ammonium sulfate, ammonium bisulfate, ammonium nitrate or sodium chloride, Atmos. Chem. Phys., 13, 11723-11734, https://doi.org/10.5194/acp-13-11723-2013, 2013.
You, Y., Kanawade, V. P., de Gouw, J. A., Guenther, A. B., Madronich, S., Sierra-Hernández, M. R., Lawler, M., Smith, J. N., Takahama, S., Ruggeri, G., Koss, A., Olson, K., Baumann, K., Weber, R. J., Nenes, A., Guo, H., Edgerton, E. S., Porcelli, L., Brune, W. H., Goldstein, A. H., and Lee, S.-H.: Atmospheric amines and ammonia measured with a chemical ionization mass spectrometer (CIMS), Atmos. Chem. Phys., 14, 12181-12194, https://doi.org/10.5194/acp-14-12181-2014, 2014a.

You, Y., Smith, M. L., Song, M., Martin, S. T., and Bertram, A. K.: Liquid-liquid phase separation in atmospherically relevant particles consisting of organic species and inorganic salts, Int. Rev. Phys. Chem., 33, 43-77, https://doi.org/10.1080/0144235x.2014.890786, 2014 b.

$\mathrm{Yu}, \mathrm{H}$. and Lee, S. H.: Chemical ionisation mass spectrometry for the measurement of atmospheric amines, Environ. Chem., 9, 190-201, https://doi.org/10.1071/en12020, 2012.

Zhang, H. F., Yee, L. D., Lee, B. H., Curtis, M. P., Worton, D. R., Isaacman-VanWertz, G., Offenberg, J. H., Lewandowski, M., Kleindienst, T. E., Beaver, M. R., Holder, A. L., Lonneman, W. A., Docherty, K. S., Jaoui, M., Pye, H. O. T., Hu, W. W., Day, D. A., Campuzano-Jost, P., Jimenez, J. L., Guo, H. Y., Weber, R. J., de Gouw, J., Koss, A. R., Edgerton, E. S., Brune, W., Mohr, C., Lopez-Hilfiker, F. D., Lutz, A., Kreisberg, N. M., Spielman, S. R., Hering, S. V., Wilson, K. R., Thornton, J. A., and Goldstein, A. H.: Monoterpenes are the largest source of summertime organic aerosol in the southeastern United States, P. Natl. Acad. Sci. USA, 115, 2038-2043, https://doi.org/10.1073/pnas.1717513115, 2018.

Zuend, A., Marcolli, C., Luo, B. P., and Peter, T.: A thermodynamic model of mixed organic-inorganic aerosols to predict activity coefficients, Atmos. Chem. Phys., 8, 4559-4593, https://doi.org/10.5194/acp-8-4559-2008, 2008.

Zuend, A., Marcolli, C., Booth, A. M., Lienhard, D. M., Soonsin, V., Krieger, U. K., Topping, D. O., McFiggans, G., Peter, T., and Seinfeld, J. H.: New and extended parameterization of the thermodynamic model AIOMFAC: calculation of activity coefficients for organic-inorganic mixtures containing carboxyl, hydroxyl, carbonyl, ether, ester, alkenyl, alkyl, and aromatic functional groups, Atmos. Chem. Phys., 11, 9155-9206, https://doi.org/10.5194/acp-11-9155-2011, 2011.

Zuend, A., Marcolli, C., Luo, B. P., and Peter, Th.: Corrigendum to "A thermodynamic model of mixed organic-inorganic aerosols to predict activity coefficients" published in Atmos. Chem. Phys., 8, 4559-4593, 2008, Atmos. Chem. Phys., 12, 10075-10075, https://doi.org/10.5194/acp-12-10075-2012, 2012. 